\title{
Stratigraphic signatures of translation of thrust-sheet top basins over low-angle detachment faults
}

\author{
Quintijn Clevis, Gerben de Jager, Wouter Nijman and Poppe L. de Boer \\ Sedimentology Group, Faculty of Earth Sciences, Utrecht University, Utrecht, The Netherlands
}

\begin{abstract}
Low-angle detachment faults and thrust-sheet top basins are common features in foreland basins. However, in stratigraphic analysis their influence on sequence architecture is commonly neglected. Usually, only eustatic sea level and changing flexural subsidence are accounted for, and when deformation is considered, the emphasis is on the generation of local thrust- flank unconformities. This study analyses the effects of detachment angle and repetitive detachment activation on stratigraphic stacking patterns in a large thrust-sheet top basin by applying a three-dimensional numerical model.

Model experiments show that displacement over low-angle faults $\left(2-6^{\circ}\right)$ at moderate rates $\left(\sim 5.0 \mathrm{~m} \mathrm{kyr}^{-1}\right)$ results in a vertical uplift component sufficient to counteract the background flexural subsidence rate. Consequently, the basin-wide accommodation space is reduced, fluvio-deltaic systems carried by the thrust-sheet prograde and part of the sediment supply is spilled over towards adjacent basins. The intensity of the forced regression and the interconnectedness of fluvial sheet sandstones increases with the dip angle of the detachment fault or rate of displacement. In addition, the delta plain is susceptible to the formation of incised valleys during eustatic falls because these events are less compensated by regional flexural subsidence, than they would be in the absence of fault displacement.
\end{abstract}

\section{INTRODUCTION}

Foreland basins are often envisaged as asymmetric systems experiencing maximum subsidence rate and accommodation space generation adjacent to the main thrust front, decreasing away from the deformation front (Heller et al., 1988). This view is too simplistic to explain stratigraphic patterns in the proximal domains of such basins, as subsidence patterns are often complicated by local tectonic deformation, basin compartmentalisation and the activity of thrustsheet top basins (Ori \& Friend, 1984; Ricci-Lucchi, 1986).

Thrust-sheet top basins are very common features in foreland basins (Beer et al., 1990; Puigdefäbregas, 1992; Talling et al., 1995; Hogan \& Burbank, 1996), and can represent more than $75 \%$ of the entire foreland basin area (Vergés $\&$ Burbank, 1996; Burkhard \& Sommaruga, 1998; Wagreich, 2001). Temporal variations in relative sea level and therefore the stratigraphic stacking patterns in these basins are controlled by eustatic and tectonic processes, of which the latter is a combination of thrust displacement and regional flexural subsidence. It is difficult to unravel the relative contribution of each process on the sequence architecture, because individual rates and frequencies of the components cannot be estimated independently. This interplay

Correspondence and Present Address: Quintijn Clevis, Department of Geological Sciences, CIRES, 2200 Colorado Avenue, Campus Box 399, Boulder, CO 80309-0399, USA. E-mail: quintus.clevis@geog.ox.ac.uk in thrust-sheet top basins is suited for evaluation by numerical forward models that couple the important processes and where the relative importance of a single component on basin architecture can be explored by systematic variation of the governing parameters. However, thrust-sheet top basin stratigraphy is not commonly addressed in modelling studies because of the numerical complexity involved in coding horizontal thrust-sheet translation and erosion at the same time. This is rapidly changing due to the increasing interest in tectono-geomorphic interaction, the availability of new dating methods such as luminescence dating in convergent neotectonic settings, and new modelling techniques sufficiently flexible to simulate thrusting and surface processes (Chaleron \& Mugnier, 1993). A notable example is a study by van der Beek et al. (2002) in which the triangular element model CASCADE (Braun \& Sambridge, 1997) is used to explain drainage diversion or incision along the Nepal Himalayan foothills as a function of detachment angle and lateral differences in displacement rate along the deformation front. They conclude that the direction and slope of the transverse drainage is primarily a function of lateral differences in propagation rate over an inclined detachment. Minor differences in convergence rate and detachment angle determine whether downstream fault-bend folds in the foothills are safeguarded from fluvial incision and the formation of wind gaps. In their study, the thrustsheet top basin is fully continental and dominated by 
(a)

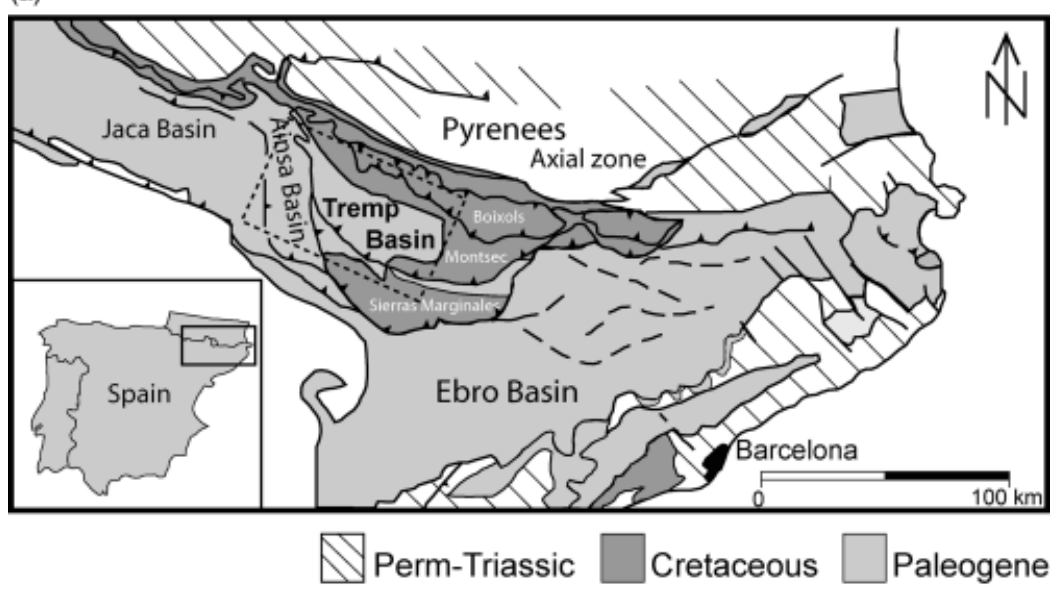

(b)

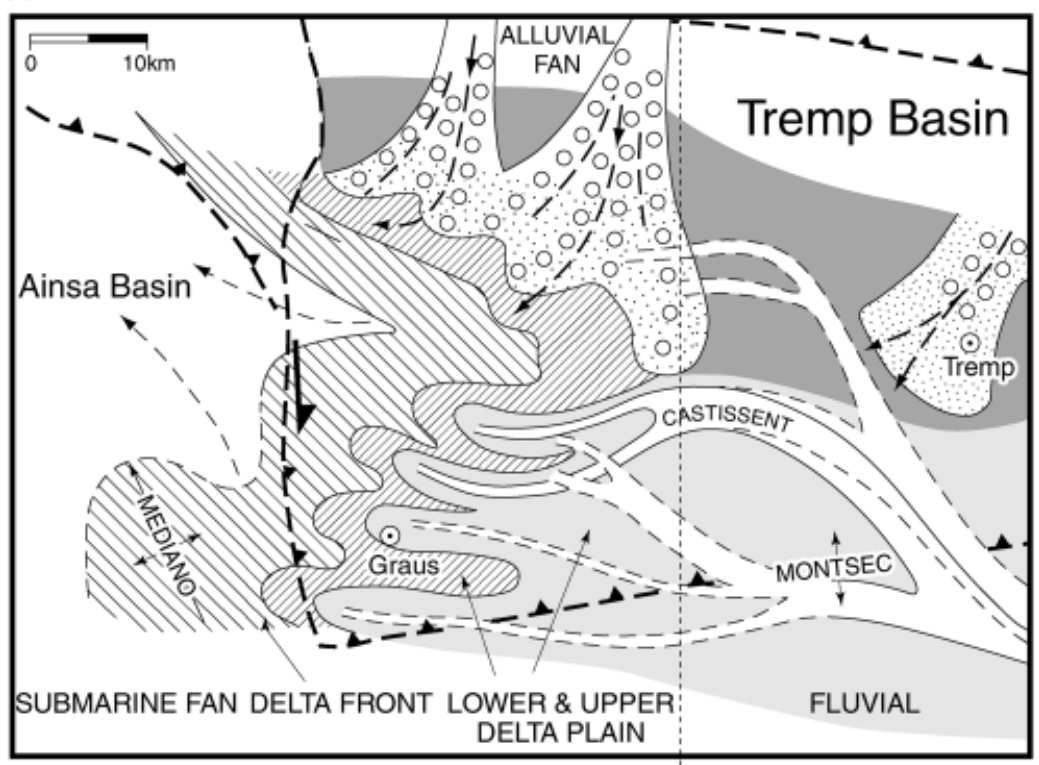

Section:Figure 2
Fig. 1. (a) Simplified geolocial map of the Spanish Pyrenees and Ebro Basin showing the location of the Tremp and Ainsa Basins (redrawn after López-Blanco et al., 2003). (b) Planview of the drainage organisation in the EoceneTremp thrust-sheet top basin during the deposition of the Montanyana Group. The basin was occupied by two depositional systems, transverse alluvial fans and an axial fluvio-delta system, which converge in the axis of the basin. The basin is bounded in the west by the lateral ramp of the carrying Coteilla-Montsec thrust-sheet, which marks the facies transition to the turbidite systems of the Hecho Group in the Ainsa Basin (modified after Nijman, 1998). The dashed line indicates the position of the cross-section in Fig. 2. erosion of the frontal fault-bend fold and the basin itself. However, thrust-sheet top basins are known to develop early in immature foreland basins and to accommodate sediment due to their position below (Ricci-Lucchi, 1986; Huyghe et al., 1999) or close to base level (Talling et al., 1995; Ramos et al., 2002). The balance between two fundamental processes - regional flexural subsidence and basin-wide uplift created by horizontal translation over a shallow hinterland-dipping detachment fault (Talling et al., 1995) - has a major impact on basin stratigraphy.

The aim of this paper is to investigate the effect of alternating activity and quiescence of a detachment fault on the evolution of a thrust-sheet top basin as a function of the detachment-fault angle. The consequent evolution of accommodation space, fluvial drainage directions, and stratigraphic patterns recorded in the basin are investigated with a numerical model. The influence of the detachment-fault angle is critically evaluated. This fundamental variable is commonly overlooked in foreland basin analy- sis, which traditionally focusses on rates of tectonic displacement and subsidence.

The structural configuration of the simulated thrustsheet top basin and the boundary conditions are based on Tremp-Ainsa Basin in the Spanish Pyrenees (Marzo et al., 1988; Nijman, 1998) (Figs 1 and 2), in order to facilitate the comparison of the modelled stratigraphy with a field situation. The Tremp Basin has been filled by the Eocene fluviodeltaic Montanyana Group, which was deposited by southwestward-prograding alluvial fans merging with an axial fluvial system, flowing parallel to the juvenile Pyrenean Orogen (Friend et al., 1981; Marzo et al., 1988). The Montanyana Group passes westward into the turbidite systems of the Hecho Group, deposited in the adjacent marine Ainsa Basin (Mutti, 1985). A considerable fraction of the material constituting these turbidite systems has been derived from the nearby structurally oversteepened delta front, positioned above the lateral ramp of the underlying Cotiella-Montsec thrust sheet. In stratigraphic 


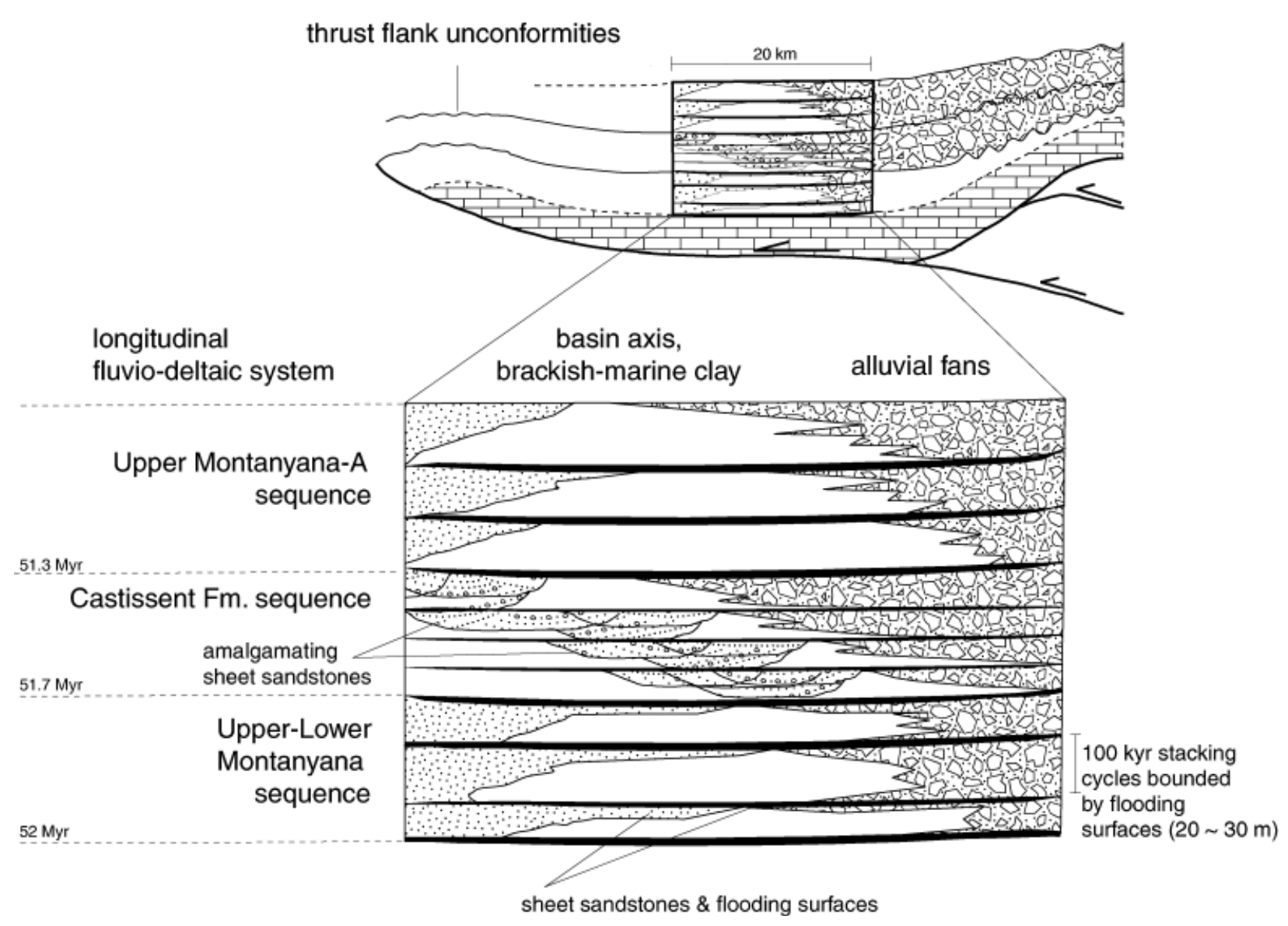

Fig. 2. Schematic representation of the Montanyana Group sequence architecture in the Tremp thrust-sheet top basin. The finegrained basin fill is partitioned into megasequences by pronounced unconformities at the basin margins, which pass into conformable stratigraphic relationships in the basin centre. Here, amalgamating sheet sandstones and marine flooding surfaces mark the boundaries. The sequences are subdivided into fan and axial-fluvial couplets bounded by flooding surfaces, each representing approximately $100 \mathrm{kyr}$ (modified after Marzo et al., 1988). For a thorough three-dimensional analysis of the basin fill architecture and tectonic interpretation of the megasequences, see Nijman (1998).

cross-section, the Montanyana Group is partitioned into several tectonic-controlled megasequences, characterised by unconformities flanking the basin margins (Nijman, 1998). These unconformities pass into conformable stratigraphic relationships, axial sheet sandstones or marine flooding surfaces in the basin centre (Fig. 2). Here, we discuss the resemblances between the modelled basin fill and the Castissent Formation or megasequence, and propose a new explanation for its stratigraphic characteristics.

\section{NUMERICAL MODEL}

\section{Surface processes}

A quantitative three-dimensional model has been developed to gain insight into tectono-geomorphological interaction and the stratigraphic response in foreland basins (Clevis, 2003). The model is based on GOLEM (Tucker \& Slingerland, 1996) and incorporates uplift by thrusting of an orogenic wedge and simultaneous erosion by bedrock collapse and fluvial bedrock incision. Erosional products are transported downstream following steepest descent and bifurcating routing schemes while using a stream power-type equation for fluvial carrying capacity. Sediment is deposited in a flexural-created foreland basin by transverse alluvial fans and an axial fluvio-deltaic system. Marine processes include diffusion-controlled clinoform deposition and in situ production of carbonates. A brief summary of the surface and tectonic processes is given here (Table 1) but a more extensive description can be found in Clevis et al. (2003) and Clevis et al. (in press). The sedimentation rules applied are simplifications of actual sediment transport processes, but allow for simulation of erosion and deposition at geological time scales, something that is currently impossible with physically based transport equations due to computational limitations.

Sediment transport capacity in the fluvial systems is expressed as the product of water discharge $Q$ and local slope 
Table 1. Main constants used in the surface and tectonic processes.

\begin{tabular}{|c|c|c|}
\hline Constant & Value & Explanation \\
\hline \multicolumn{3}{|l|}{ Fluvial transport } \\
\hline$K_{\mathrm{f}}($ axial delta $)$ & $0.1 \mathrm{~m}^{-3 / 2} \mathrm{yr}^{1 / 2}$ & Fluvial transport coefficient \\
\hline$K_{\mathrm{f}}$ (alluvial fans) & $0.01 \mathrm{~m}^{-3 / 2} \mathrm{yr}^{1 / 2}$ & Fluvial transport coefficient \\
\hline$m_{\mathrm{f}}, n_{\mathrm{f}}$ & $3 / 2,1$ & Discharge and slope exponent \\
\hline $\mathrm{d} t$ & 10 years & Geomorphic timestep size \\
\hline $\mathrm{d} x$ & $500 \mathrm{~m}$ & Uniform cell size \\
\hline$Q_{\text {sed-influx }}$ & $0.8 \mathrm{~km}^{3} \mathrm{yr}^{-1}$ & Axial sediment influx \\
\hline$Q_{\text {w-influx }}$ & $8000 \mathrm{~km}^{3} \mathrm{yr}^{-1}$ & Axial water influx \\
\hline \multicolumn{3}{|l|}{ Bedrock erosion } \\
\hline$K_{\mathrm{b}}$ & $1.0 \times 10^{-4} \mathrm{yr}^{-2 / 3}$ & Bedrock erosion coefficient \\
\hline$m_{\mathrm{b}}, n_{\mathrm{b}}$ & $1 / 3,2 / 3$ & Discharge and slope exponent \\
\hline$P_{\text {rain }}$ & $1.0 \mathrm{~m} \mathrm{yr}^{-1}$ & Uniform rainfall rate \\
\hline \multicolumn{3}{|l|}{ Bedrock collapse } \\
\hline$C$ & $6 \times 10^{4} \mathrm{~kg} \mathrm{~m}^{-1} \mathrm{~s}^{-2}$ & Cohesion \\
\hline$\beta$ & (deg.) & Actual slope \\
\hline$\phi$ & $20^{\circ}$ & Bedrock friction angle \\
\hline \multicolumn{3}{|l|}{ Marine (deltafront collapse) } \\
\hline$C$ & $600 \mathrm{~kg} \mathrm{~m}^{-1} \mathrm{~s}^{-2}$ & Cohesion \\
\hline$\beta$ & (deg.) & Actual slope \\
\hline$\phi$ & $1^{\circ}$ & Slope mud friction angle \\
\hline$K_{\mathrm{m}}$ & $0.1 \mathrm{~km}^{3} \mathrm{yr}^{-1}$ & Diffusion coefficient at $15 \mathrm{~m}$ depth \\
\hline$R_{\text {carbonate }}$ & $0.1 \mathrm{~km}^{3} \mathrm{yr}^{-1}$ & Carbonate accumulation rate \\
\hline \multicolumn{3}{|l|}{ Tectonics } \\
\hline$\theta_{\text {orogenic ramp }}$ & $20^{\circ}$ & Thrust fault angle \\
\hline$\theta_{\text {detachment fault }}$ & $2^{\circ}, 4^{\circ}$ and $6^{\circ}$ & Thrust fault angle \\
\hline$\theta_{\text {frontal thrust }}$ & $20^{\circ}$ & Thrust fault angle \\
\hline$V_{\text {hor }}$ & $5 \mathrm{~m} \mathrm{kyr}^{-1}$ & Uniform horizontal displacement field \\
\hline$V_{\text {vert }}=V_{\text {hor }} \tan \left(\theta_{\text {fault }}\right)$ & $(-) \mathrm{m} \mathrm{kyr}^{-1}$ & Resulting vertical uplift rate \\
\hline \multicolumn{3}{|l|}{ Flexure } \\
\hline$E, v$ & $70 \mathrm{Gpa}, 0.25$ & Young's modulus and Poisson's ratio \\
\hline$D\left(T_{\mathrm{e}}=15 \mathrm{~km}\right)$ & $2.1 \times 10^{22} \mathrm{Nm}$ & Flexural rigidity \\
\hline$D\left(T_{\mathrm{e}}=30 \mathrm{~km}\right)$ & $1.68 \times 10^{23} \mathrm{Nm}$ & Flexural rigidity \\
\hline$\rho_{\text {inf }}$ & $\operatorname{sed} 2250 \mathrm{~kg} \mathrm{~m}^{-3}$ & Infill density \\
\hline$\rho_{\text {inf }}$ & bedr $2700 \mathrm{~kg} \mathrm{~m}^{-3}$ & Infill density \\
\hline$\rho_{\mathrm{m}}$ & $\operatorname{mant} 3300 \mathrm{~kg} \mathrm{~m}^{-3}$ & Mantle density \\
\hline
\end{tabular}

S (Tucker \& Slingerland, 1996; Whipple \& Tucker, 2002). In the absence of tectonic subsidence or uplift, the change in height of an alluvial cell is a function of carrying capacity along the transport path:

$\frac{\partial h_{\text {cell }}}{\partial t}=-\frac{K_{\mathrm{f}}}{W}\left(\frac{\partial Q^{m_{\mathrm{f}}} S^{n_{\mathrm{f}}}}{\partial x}+\frac{\partial Q^{m_{\mathrm{f}}} S^{n_{\mathrm{f}}}}{\partial y}\right)$

where $W$ is the channel width, which can be approximated using an empirical equation (Leopold \& Maddock, 1953), $K_{\mathrm{f}}$ is a fluvial transport stream power coefficient, and the discharge and slope exponents $m_{\mathrm{f}}$ and $n_{\mathrm{f}}$ are 1.5 and 1.0 (Murray \& Paola, 1997; Crave \& Davy, 2001). Equation is generally used for bedload rivers and has also been successfully applied to model lowland rivers and shelf systems (Meijer, 2002). Two values for $K_{\mathrm{f}}$ are used in the model, one for the alluvial fans (0.01) and one for the axial system (0.1). These values are chosen because they give realistic and numerically stable values for depositional equilibrium slopes and sedimentation rates for both fluvial systems in combination with the coarse computational grid $(500 \mathrm{~m})$ and geomorphic time-step size (10 years) in an unperturbed basin. The applicability of these values therefore strongly depends on the spatial discretisation and timestep size used. However, a similar 10-fold difference in transportability between both systems is argued by Marr et al. (2000) while calculating diffusivities for gravel and sand-bed rivers.

Within the model space a tracer routine tracks the provenance composition of the transported material and determines which of the two $K_{\mathrm{f}}$ values is used at a location in the basin. Each fluvial system carries a sediment load composed of two 'grain size' fractions, gravel and sand on the fan surfaces, and sand and clay in the axial system. During multiple evaluations of erosion and deposition along the stream paths through the computational grid, the coarse fractions are segregated from the finer ones using the perfect sorting principle, which is based on selective deposition of the least transportable fractions (Paola et al., 1992; Clevis et al., 2003). 
In absence of a sediment cover, the change of height of a cell is determined by the rate of bedrock incision, which is again a function of discharge and slope (Howard, 1994)

$\frac{\partial h_{\mathrm{b}}}{\partial t}=-K_{\mathrm{b}} Q^{m_{\mathrm{b}}} S^{n_{\mathrm{b}}}$

where $K_{\mathrm{b}}$ is the bedrock erodability coefficient with a value of $1.0 \times 10^{-4}$ myear $^{-2 / 3}$. This value approximates an average erodability of bedrock as derived by inverse modelling of fluvial profiles (Stock \& Montgomery, 1999). The effect of erodability values on drainage basin morphology and sediment flux is explored in Clevis et al. (2003) and not further discussed here. Exponents $m_{\mathrm{b}}$ and $n_{\mathrm{b}}$ are $1 / 3$ and $2 / 3$, respectively, as these values resulted in a well-calibrated fit between modelled and observed topography of the Zagros fold-and-thrust belt (Tucker, 1996).

In addition, high sloping bedrock cells are eroded using the Cullman stability criterion (Spangler \& Handy, 1982; Densmore et al., 1998; Champell et al., 2002), which predicts a maximal stable height $H_{\mathrm{c}}$ relative to a neighbouring cell

$H_{\mathrm{c}}=\frac{4 C}{\rho g} \frac{\sin \beta \cos \phi}{[1-\cos (\beta-\phi)]}$

where $C$ is the effective cohesion on the fault plane, $\phi$ is the effective friction angle on the fault, $\rho$ is the rock density, $g$ is gravitation constant and $\beta$ is the surface slope. The probability of failure $P$ is expressed as the ratio of actual height $H$ vs. critical height $H_{\mathrm{c}}$ and evaluated using a random number routine every geomorphic time step.

$P_{\text {collapse }}=\frac{H}{H_{\mathrm{c}}}$

The size of a landslide is determined by accumulating all failed mass around the trigger cell, and has a maximum width of $1.5 \mathrm{~km}$ (Clevis et al., in press). The landslide is distributed in multiple downstream directions and has an empirical determined run-out length of $5 \mathrm{~km}$ (Blair, 1999). Bedrock incision and collapse is evaluated for all bedrock-floored cells and no distinction is made between fluvial and hillslope cells, because of the coarse resolution of the model. Sediment produced by both erosion processes is composed of $50 \%$ coarse and $50 \%$ fine grain size fraction and is distributed further downstream by fluvial transport (Eqn. (1)).

A fluvial cell entering the marine realm is instructed to deposit all its bedload until the local accommodation space below base level is filled. Excess sediment is distributed to neighbouring marine cells in proportion to the local gradient. Within the marine realm sediment, transport is modelled by diffusion because of its ability to produce realistic looking clinoform profiles in deltaic fronts (Kenyon \& Turcotte, 1985; Syvitski \& Daughney, 1992). Marine cells that do not receive any clastic input during a geomorphic time-step accumulate carbonate using a production rate that decreases exponentially with water depth (Demicco, 1998; Clevis et al., in press).

\section{Model set-up and structural geometry}

The model set-up consists of a grid of $150 \times 150,500-\mathrm{m}$ cells in which the positions of fault planes are predefined (Fig. 3). A frontal thrust ramp is connected to the orogenic wedge by a shallow hinterland-dipping sole thrust, detaching the foreland basin and transforming it to a thrust-sheet top basin. The structures delineate fields in which deformation is calculated in the $-j$ direction at $5 \mathrm{~m} \mathrm{kyr}^{-1}$ using a kinematic velocity description of deformation (Contreras \& Suter, 1990; Hardy \& Poblet, 1995), and where the corresponding vertical uplift is achieved by advection of topography over inclined thrust ramps. The resulting vertical uplift rate depends on the slope of the thrust ramps and can be described as $V_{\text {vertical }}=$ $V_{\text {horizontal }} \tan \left(\theta_{\text {fault }}\right)$ (Fig. 3). In contrast to the geomorphic steps of 10 years, the horizontal displacement fields are applied incrementally in larger steps of 1000 years, because the tectonic routines are computationally intensive. As the displacement during a single tectonic step of 1000 years is smaller than the grid discretisation, $5 \mathrm{~m}$ compared with $500 \mathrm{~m}$, the tectonic translation is performed using a spatial interpolation technique that conserves volume (Clevis et al., 2003, their Fig. 5). Both fault planes are allowed to expand in the slip direction and also adjust vertically to regional flexure, but they do not grow laterally. The blind thrust fault separating the orogenic wedge from the thrust-sheet top basin is translated while being carried on the active detachment fault. The thrust structures are bounded to the left by a strike slip fault marking the transition to a marine basin, which experiences no deformation only continuous flexural subsidence (Fig. 4). This geometry is a simplification of the actual tectonic boundary between the Tremp and the Ainsa Basins, which is given by the oblique ramp of the Cotiella-Montsec thrust sheet (Fig. 1). This ramp is marked by a complex of blind thrusts, anticlinal culminations and growth strata relationships that indicate lateral growth during the deposition and progradation of the axial delta (de Boer et al., 1991; Holl \& Anastasio, 1995; Poblet et al., 1995; Dreyer et al., 1999; López-Blanco et al., 2003). As result of the complexity of the selected basin configuration, three routines had to be added to the foreland basin model to handle the:

- syn-sedimentary horizontal translation of the detailed stratigraphic fill of the thrust-sheet top basin;

- three-dimensional flexure due to thrust, sediment and water loading;

- and delta slope collapse, delivering sediment to the adjacent marine basin.

\section{Horizontal translation of thrust-sheet top stratigraphy}

The detailed stratigraphic information stored in the detached thrust-sheet top basin is translated using a computational intensive interpolation technique, which is a modification of a routine originally developed for relocating individual nodes and their stratigraphy during the 


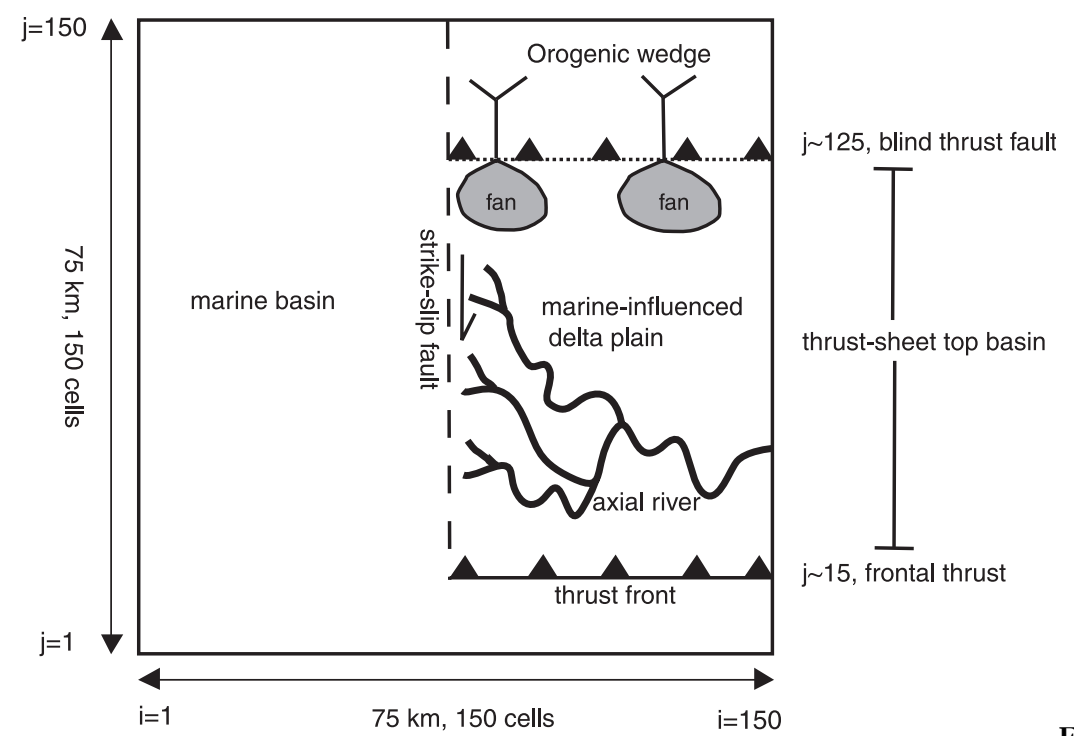

Fig. 3. Basin geometry used in the numerical experiments $(150 \times 150$ cells, $75 \times 75 \mathrm{~km})$. The initial model landscape starts as a flat surface

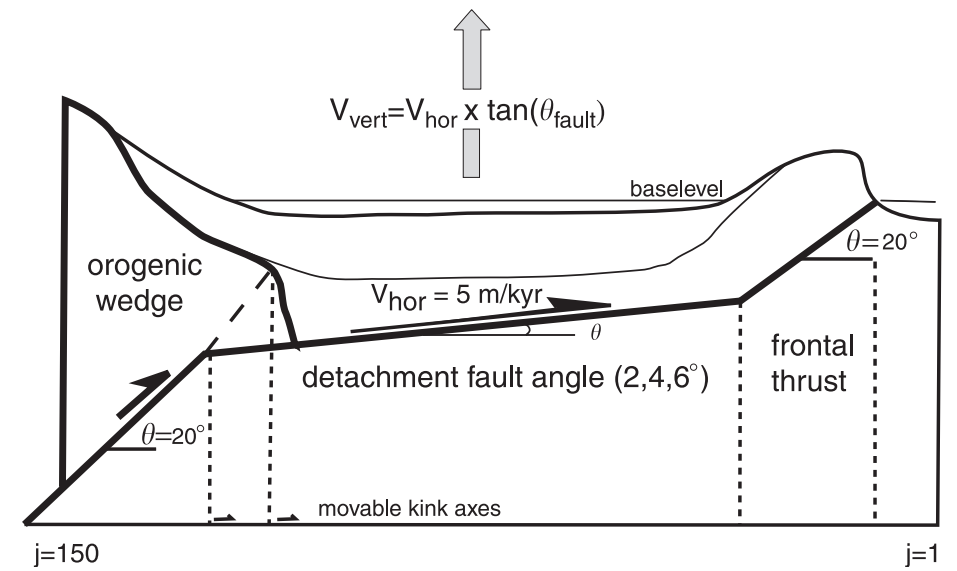
positioned at baselevel $(0 \mathrm{~m})$. The basin is divided into two domains by a strike-slip fault. The domain on the right experiences deformation by a moving orogenic front and displacement of the thrust-top basin along a detachment fault. The marine basin on the left solely experiences regional flexural subsidence. The segmented foreland basin is filled by an axial-delta system entering from the right-hand side with a constant supply of $0.8 \mathrm{~km}^{3} \mathrm{kyr}^{-1}$ and by the erosional debris shed off from the uplifting orogenic wedge $\left(\sim 0.1 \mathrm{~km}^{3} \mathrm{kyr}^{-1}\right)$ The grid boundary at the lefthand side is open and functions as an ultimate sediment sink. The fault geometry is based on Muñoz (1992) and Nijman (1998).

creation of a meander bend in the CHILD model (Tucker et al., 2002). Instead of a few nodes, in this case an entire mesh of nodes needs to be moved. Each of the grid nodes representing the basin landscape is connected to a linkedlist data structure (Oualine, 1997), which stores the stratigraphic stack of layers at that grid location (Fig. 5). Every layer in such a linked list carries lithological information about its texture and provenance (marine, alluvial fan or axial delta), chronological information about depositional 'starting' age and, when the layer was recently involved in erosion or sedimentation, its 'recent activity'age. The layer stacks are continuously updated during the erosion and deposition events, and the resolution of the stratigraphy is limited by user-defined maximum layer thickness of $1.0 \mathrm{~m}$ or a depositional lifetime of 2000 years.

The chronological information of the layers is used in the translation of the thrust-sheet top basin fill (Fig. 5). The tectonic displacement field predicts new positions for the piggyback basin nodes, but because the model is based on a fixed equidistant grid, they are not allowed to move. The solution is to assign new locations to the stratigraphic linked lists, temporally, and to interpolate a new stack of layers for the static node positions by weighted distance interpolation between two displaced locations. Interpolation and averaging of properties between layers is allowed if their recent activity ages differ by less than a user-defined time span, here set to 500 years. If this requisite is not fulfilled, the layers are advected into the newly created stack, according to chronological recent activity age (Fig. 5). The technique is here applied to simulate the translation of a thrust-top basin fill on a fixed grid, but is also applicable to other tectonic processes involving a horizontal component, such as strike-slip or normal faulting.

\section{Three-dimensional flexure}

The activation of intra-foreland basin thrust structures results in a variable loading of the lithosphere due to the discontinuous nature of the frontal thrust (Figs 3 and 4) and the subsequent redistribution of the sediment. The model is therefore extended with a two-dimensional flexure solution based on the FourierTransform method (Karner, 1982; Wees \& Cloetingh, 1994; Hodgetts et al., 1998). The algorithm applied here is based on Mathcad script 6.2 , accompanying the book on lithospheric flexure by Watts (2001; page 239). The governing equation for flexural 
(a)

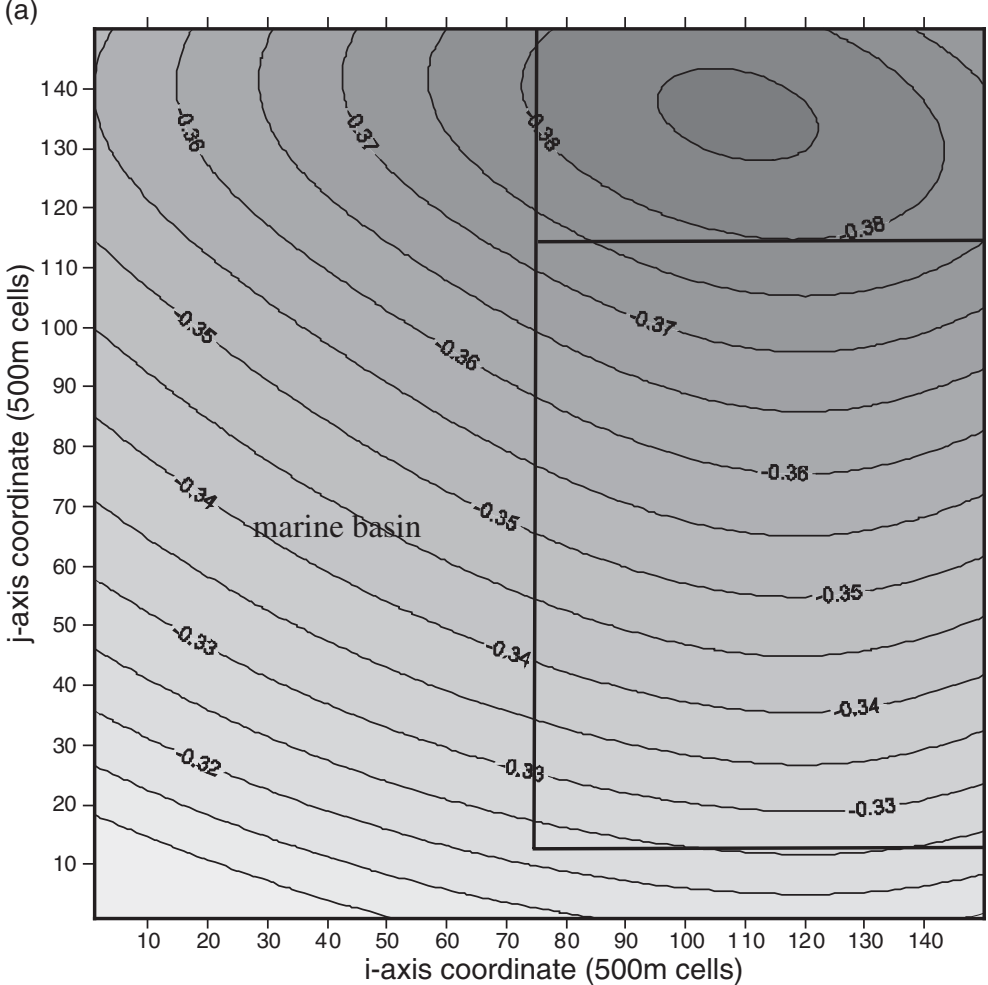

blind

thrust

fault

(b)

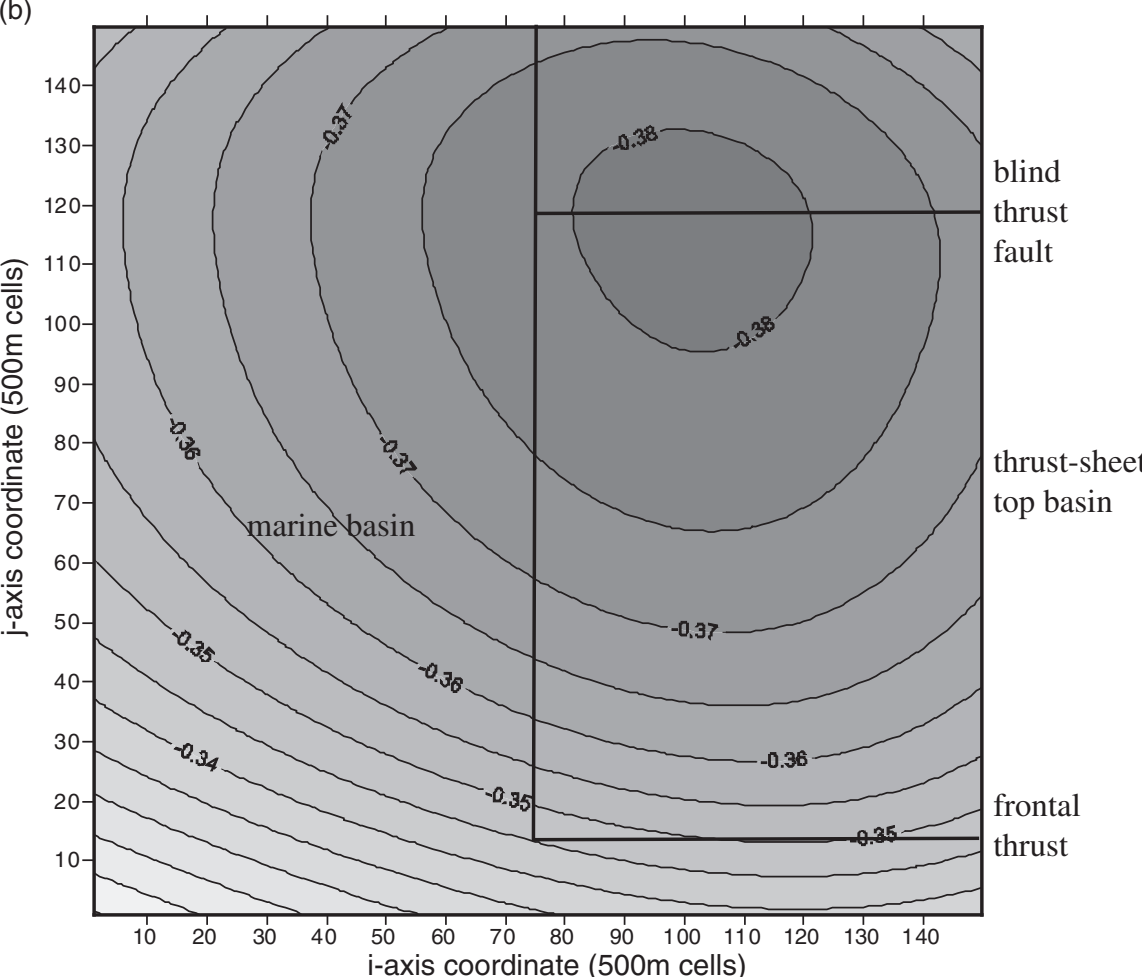

flexural subsidence rate $(\mathrm{m} / \mathrm{kyr})$

\begin{tabular}{|l|l|l|l|l|l|l|l|l|l|l|l|l|l|l|l|l|l}
$-0,31$ & -0.32 & -0.33 & $-0,34$ & $-0,35$ & -0.36 & $-0,37$ & -0.38 & -0.39 \\
\hline & & & & & & & & & & & & & & & & \\
\hline
\end{tabular}

Fig. 4. Flexural subsidence fields in the model space $\left(\mathrm{m} \mathrm{kyr}^{-1}\right)$ during (a) activity of the orogenic wedge, (b) detachment activity. Note that during detachment activity the zone of maximum subsidence rate elongates towards the foreland while the subsidence rates underneath the thrust-sheet top basin slightly increase. 


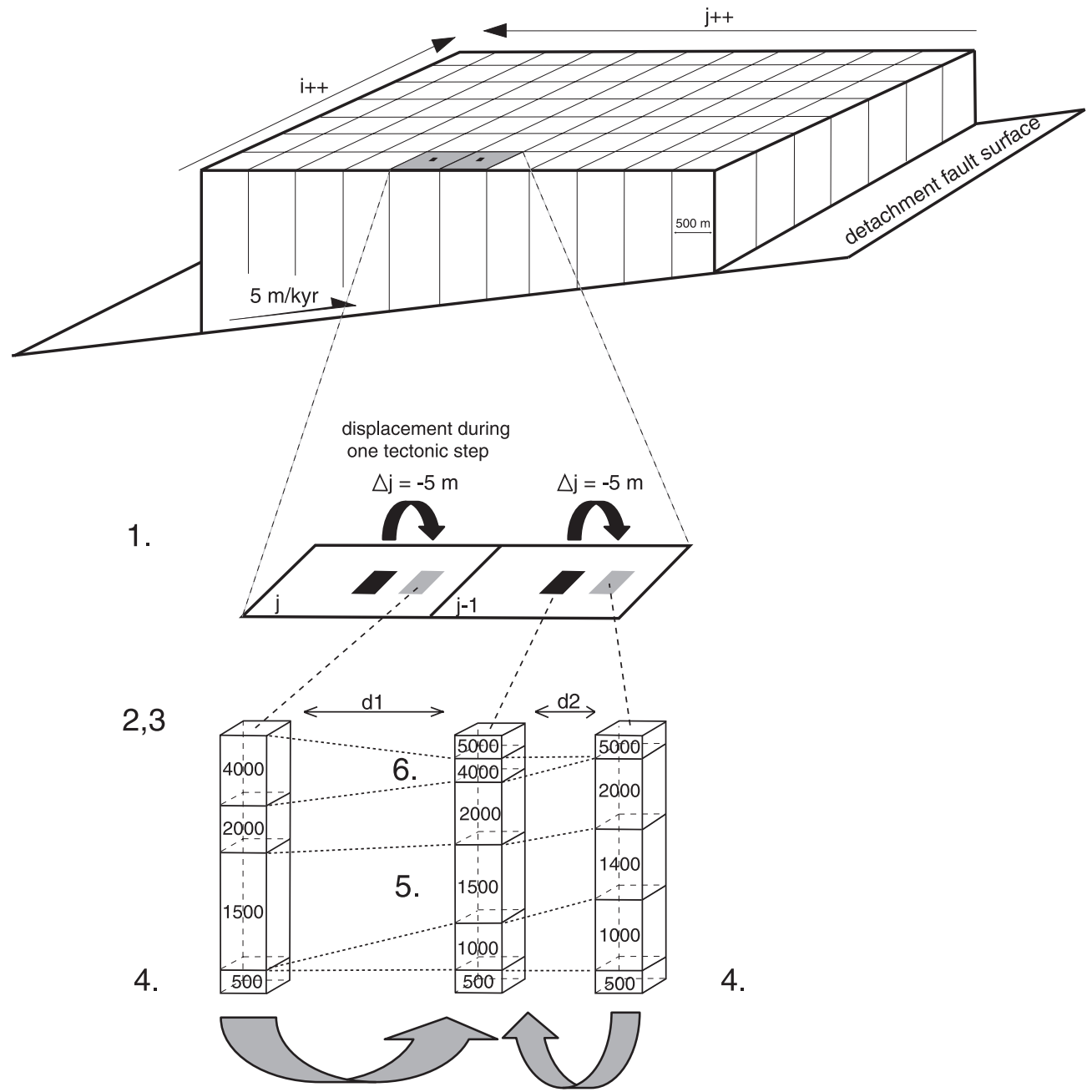

Create a new stack of layers for the static grid cell centre position $\mathrm{j}-1$ by interpolation between the properties of two displaced stacks

Fig. 5. Simplified explanation of the stratigraphic interpolation routine used to translate the stratigraphic information of the piggyback basin fill. (1) New node positions are calculated as function of the uniform tectonic displacement field of $5 \mathrm{~m} \mathrm{kyr}^{-1}$ in the $-j$ direction. (2) The distances between the new node positions and the static grid are calculated. (3) These distances are used in weighted interpolation of layer properties. (4) Comparison of the layers, starting at the base of the stratigraphy. (5) If layers fall in the same age range (500 years), new layer properties are calculated using weighted interpolation between two matching layers. The age of the composite layer is set to the youngest value. (6) If layers do not match in age range the new layer is advected into pile, so that the sequence of layers in of the column is still in chronologic order.

deflection in two dimensions is

$$
\begin{aligned}
& \left(\frac{\partial^{2}}{\partial x^{2}}+\frac{\partial^{2}}{\partial y^{2}}\right) D\left(\frac{\partial w_{(x, y)}}{\partial y^{2}}+\frac{2 \partial w_{(x, y)}}{\partial x^{2} \partial y^{2}}+\frac{\partial^{2} w_{(x, y)}}{\partial x^{2}}\right) \\
& +\left(\rho_{\mathrm{m}}-\rho_{\text {inf }}\right) g w_{(x, y)}=L_{(x, y)}
\end{aligned}
$$

where $D$ is the flexural rigidity, $w_{(\mathrm{x}, \mathrm{y})}$ is the lithospheric deflection resulting from the load $L_{(x, y)}$, both being a function of spatial coordinates $x$ and $y, \rho_{\mathrm{m}}$ is the density of the mantle and $\rho_{\text {inf }}$ is the density of the imposed load (either, bedrock, sediment or water). Expressed in the wave number domain, Eqn. (5) becomes

$W_{(i, j)}=R_{(i, j)} g L_{(i, j)}$ where $W_{(i, j)}$ is the Fourier transform of $w_{(\mathrm{x}, \mathrm{y})}, L_{(\mathrm{i}, \mathrm{j})}$ the Fourier transform of $L_{(\mathrm{x}, \mathrm{y})}$, subscript $i$ is the wave number in the $x$-direction and $j$ the wave number in the $y$-direction. The response function $R_{(\mathrm{i}, \mathrm{j})}$ defines the isostatic compensation for a certain load:

$R_{(i, j)}=\frac{1}{\left(\rho_{\mathrm{m}}-\rho_{\mathrm{inf}}\right)+D\left(i^{2}+j^{2}\right)^{2}}$

An assumption in the lithospheric response algorithm is that the isostatic adjustment upon an increment of thrust or sediment loading is completed for $90-95 \%$ within a time span of $10 \mathrm{kyr}$. This rate of lithospheric response is comparable with the pace of crustal rebound associated with postglacial ice cap melting (Forman, 1990; Peltier, $1990)$ and is therefore a reasonable assumption. 
The equations are solved using a two-dimensional fast Fourier transform (FFT) algorithm (Press et al., 1992). Such algorithms are developed for signal-processing studies and are not directly applicable for solving the flexure problem, because the method assumes that the input data series is periodic. Of course, this does not hold for the spatial distribution of a tectonic load, which is non-periodic and spatially confined. Applying a FFT algorithm could result in series of interference patterns because deflections are felt at large distance from the load (10's of kilometres) and will interfere. One way of solving this FFT 'artefact' is to wrap up the actual load in a synthetic load, which on average equals the minimum load, a technique called 'copy padding' (Hodgetts et al., 1998; their Fig. 3). The expanded data series used for padding should have dimensions larger than the wavelength over which the lithosphere flexes due to the load, which is given by $\lambda=2 \pi \alpha$, where $\alpha$ is the flexural parameter given by

$\alpha=\left(\frac{4 D}{\rho_{\mathrm{m}}-\rho_{\text {inf }}}\right)^{1 / 4}$

This large area (100's of kilometres) is not entirely modelled with the surface process equations due to computational limitations. Flexure-related phenomena such as forebulge uplift and migration are calculated but occur outside the area addressed by surface processes and are therefore not recognisable in the model results.

\section{Submarine slope collapse and mass-flow deposition}

Continuous flexural subsidence and displacement-induced uplift over the inclined detachment fault causes an elevation difference between the marine basin and the thrust-sheet top basin carrying the delta. A simple marine slope collapse routine is added to the surface process equations in order to simulate sediment supply from the structurally oversteepened delta front to the deeper marine part of the basin configuration (Figs 1 and 3). A relevant question is to what extent the number of collapse events and the spatial distribution of mass-flow deposits correspond with the timing of thrust-sheet translation and eustatic sea-level variation (Mutti, 1985; Pickering et al., 1995; Pickering \& Corrigidor, 2003). In the model, gravity-flow transport to deeper water is predicted using an adapted version of the Cullman slope-stability criterion (Eqn. (4)), wherein the probability of slides is dependent on the cohe- sion $C$ of the delta front sediments, taken to be $600 \mathrm{kPa}$, and a friction angle $\phi$ of $1^{\circ}$ (Loseth, 1999). This low friction angle value is used because the material is assumed to be wet, and the resulting scar slopes $\left(3-5^{\circ}\right)$ approximate the shallow dip of deltafront slump structures in the field. The volume and composition of the failed material is determined by accumulating all failed mass in a zone of one cell width around the trigger cell. The material supplied by the collapsing delta front is distributed to deeper water according to a run-out length of $10 \mathrm{~km}$, which corresponds to the distance between the lateral ramp of the Tremp Basin and the location of the larger turbidite systems in the Ainsa Basin. A 'turbidite' in the model is represented by a flow that spreads in multiple directions proportional to slope until it is depleted at the maximum travel distance. The flow is capable of filling in irregular submarine topography and its grain size composition is sorted using perfect sorting (Paola et al., 1992). This approach represents a very simple, first-order approximation for turbidity deposition.

\section{MODEL EXPERIMENTS AND BOUNDARY CONDITIONS}

Four scenarios are modelled in order to analyse the influence of the balance between regional flexural subsidence and displacement-induced uplift along the detachment fault on the stratigraphic patterns recorded in the thrusttop basin (Table 2 and Fig. 6). In the first three experiments, the angles of the detachment fault are $2^{\circ}, 4^{\circ}$ and $6^{\circ}$, while retaining the effective elastic thickness, $T_{\mathrm{e}}$, constant at $15 \mathrm{~km}$. The angles of the detachment fault, displacement and subsidence rates generated are comparable with values inferred from the ECORS section and the Eocene Tremp Basin (Muñoz, 1992; Nijman, 1998; Beaumont et al., 2000). The value for $T_{\mathrm{e}}$ corresponds to an average flexural subsidence rate of $\sim 0.36 \mathrm{~m} \mathrm{kyr}^{-1}$, which is relatively constant over the model basin width of $75 \mathrm{~km}$ and during the simulation time (Fig. 4). A $T_{\mathrm{e}}$ of $15 \mathrm{~km}$ is chosen because the resulting subsidence rate matches the average sedimentation rate for the Montanyana Group (Nijman, 1998). Other estimates for elastic thickness during the Middle Lutetian in the Pyrenees range between 18 and $26 \mathrm{~km}$ (Millán et al., 1995), and a fourth experiment is conducted using a higher effective elastic thickness of $30 \mathrm{~km}$ and a detachment angle of $4^{\circ}$. This results in a lower average subsidence rate of $\sim 0.18 \mathrm{~m} \mathrm{kyr}^{-1}$.

Table 2. Flexural subsidence rate and displacement-induced vertical uplift in the thrust-top basin applied in the model experiments

\begin{tabular}{|c|c|c|c|c|}
\hline Exp. & $\begin{array}{l}\text { Effective elastic } \\
\text { thickness (Te, } \mathrm{km})\end{array}$ & $\begin{array}{l}\text { Average flexural } \\
\text { subsidence rate }\left(\mathrm{m} \mathrm{kyr}^{-1}\right)\end{array}$ & $\begin{array}{l}\text { Detachment } \\
\text { angle }\left(^{\circ}\right)\end{array}$ & $\begin{array}{l}\text { Vertical uplift component } \\
\text { due to } 5 \mathrm{~m} \mathrm{kyr}^{-1} \text { translation } \\
\text { on the detachment fault }\left(\mathrm{m} \mathrm{kyr}^{-1}\right)\end{array}$ \\
\hline 1 & 15 & 0.36 & 2 & 0.16 \\
\hline 2 & 15 & 0.36 & 4 & 0.32 \\
\hline 3 & 15 & 0.36 & 6 & 0.48 \\
\hline 4 & 30 & 0.18 & 4 & 0.32 \\
\hline
\end{tabular}




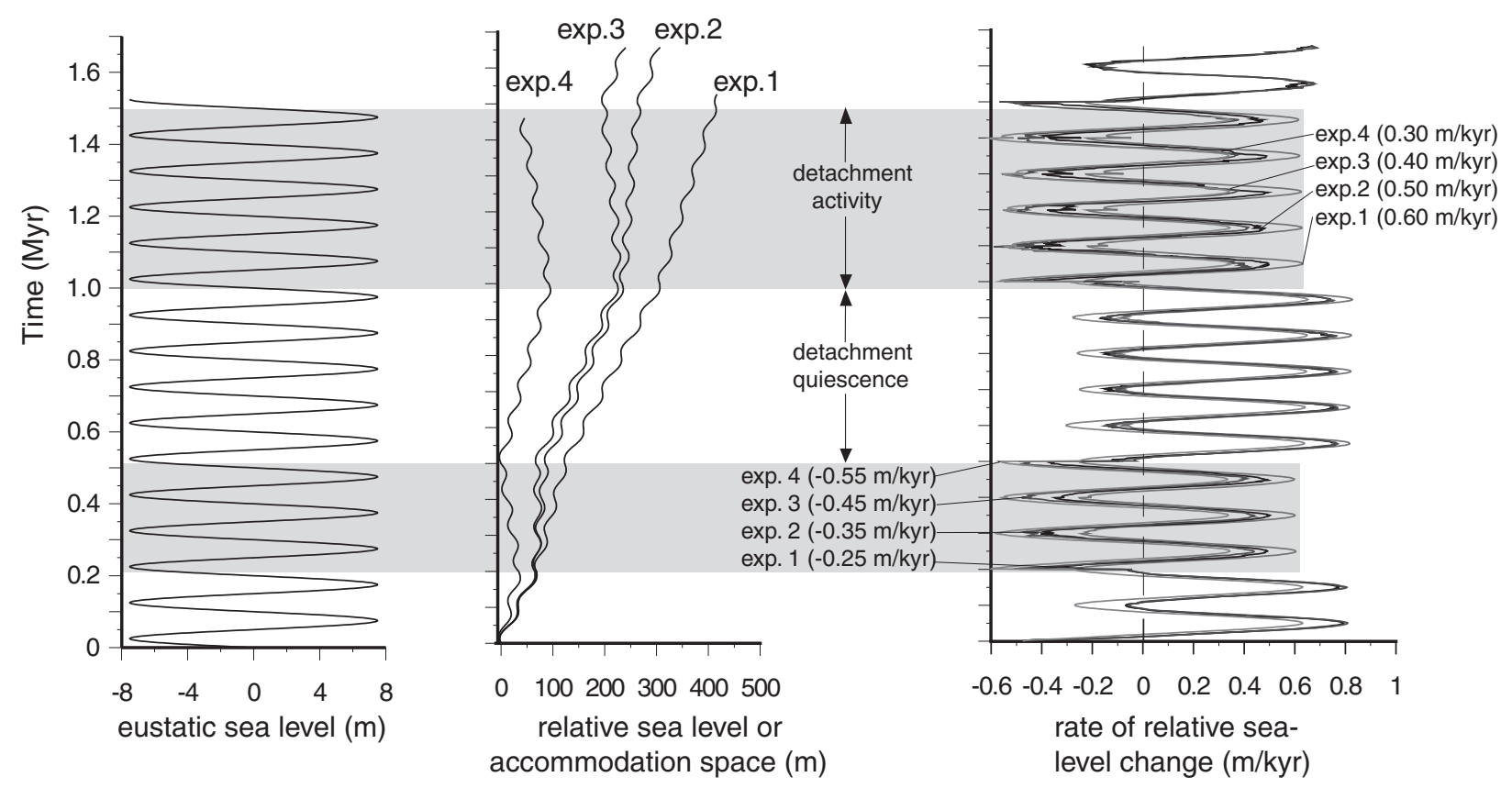

Fig. 6. The combined effect of flexural subsidence, detachment activity and eustatic sea-level fluctuation on the thrust-top basin accommodation space as a function of time. The shaded regions represent periods of activity of the detachment fault. The numbers in parentheses indicate the minimum and maximum rates of relative sea-level change per experiment. A stepwise increase in detachment angle (experiments 1-3) results in reduced accommodation space and higher rates of relative sea-level fall, promoting incision of the thrust-top basin fill.

Analysis of balanced cross-sections indicates displacement rates over the basal detachment during the deposition of the Montanyana Group range from 2 to $20 \mathrm{~m} \mathrm{kyr}^{-1}$ (Muñoz, 1992; Holl \& Anastasio, 1995; Bentham \& Burbank, 1996; Poblet et al., 1998). The average, long-term translation rate proposed is $5 \mathrm{~m} \mathrm{kyr}^{-1}$ (Vergés et al., 2002) and used in the experiments.

The activity history of the thrusts is identical in all experiments with alternating activity between structures. The first thrust structure, separating the orogenic wedge from the thrust-sheet top basin is active from 0 to $0.2 \mathrm{Myr}$ and 0.5 to $1.0 \mathrm{Myr}$. The second structure including the frontal thrust, the detachment fault, and the lower part of the orogenic ramp is active between 0.2 and $0.5 \mathrm{Myr}$, and again between 1.0 and 1.5 Myr (Figs 3 and 6). The complete fault system accommodates a horizontal shortening rate of $5.0 \mathrm{~m} \mathrm{kyr}^{-1}$, applied in incremental steps of $5 \mathrm{~m}$ per 1000 years during the course of the simulations. The pulsed behaviour of partitioning of slip to the frontal thrust structures is inferred from regional studies in the Pyrenean foreland (Meigs, 1996; Meigs et al., 1996; Nijman, 1998; Vergés et al., 2002) that indicate both piggyback and outof-sequence deformation styles during the Eocene (Fig. 6). The duration of the tectonic intervals $(\sim 0.3-$ $0.5 \mathrm{Myr}$, Fig. 6) is an average for the time span covered by the tectonic megasequences of the Montanyana Group (Nijman, 1998; Fig. 2), although the exact timing applied in the model experiments is arbitrary.

Individual units in the architectural stacking pattern have an approximate duration of $100 \mathrm{kyr}$ (Fig. 2) (Marzo et al., 1988; Nijman, 1998). In our model study, this frequency component is introduced as sinusoidal sea-level variations. The relatively small sea-level amplitude of $7.5 \mathrm{~m}$ is chosen because it avoids complete flooding of the upper delta plain outside the model space, and creates appropriate thicknesses of the stacking cycles in combination with the subsidence and sediment supply rates to the axial system. Water and sediment supply rates to this system are held constant throughout the scenarios presented, at 8000 and $0.8 \mathrm{~km}^{3} \mathrm{kyr}^{-1}$. As a basis for these values, the time-averaged volumetric sedimentation rates of the complete Montanyana Group were used (Nijman \& van Oosterhout, 1993; Nijman, 1998). The supply ratio is derived from the general notion that the average sediment/water discharge ratios for large rivers fluctuate around 1: 10000 (Milliman \& Syvitski, 1992). The axial sediment entering the system is composed of $10 \%$ sand and 90\% finer-grained sediment (Burgess \& Hovius, 1998). The position of the inlet is also kept constant throughout the experiments, because it is still debated whether the axial system in the Tremp Basin was sourced by upstream alluvial fans in the east (Marzo et al., 1988) or by remote drainage basins on a southern forebulge high (Nijman, 1998).

\section{EXPERIMENTAL RESULTS}

\section{Thrust-sheet top basin landscape evolution}

Landscape evolution of experiments 2 and 3 is shown in Fig. 7. Initially, the thrust-sheet top basin is relatively shallow $(\sim 30 \mathrm{~m})$ in both experiments and occupied 
by an upward convex delta body characterised by a disperse, bifurcating channel pattern (Fig. 7a, 0.2 Myr). During subsequent activation of the detachment fault and displacement of the basin, the delta progrades, and linear drainage systems on the lower delta plain develop (Fig. 7a, $0.5 \mathrm{Myr}$ ). The transition between these linear drainages on the lower delta plain to bifurcating channels on the upper delta plain marks the change in erosion/aggradation balance in the channels. The linear channels are dominated by sediment bypass or channel-bed erosion, whereas the bifurcating channels accumulate sediment. Geographically, the transitions delineate the position of a knickpoint front, triggered by the $0.45-0.50 \mathrm{Myr}$ fall in eustatic sea level. The rate of migration of the knickpoint front is $5.0 \mathrm{~km} \mathrm{kyr}^{-1}$ and diminishes in the basin centre (Fig. 7a, $0.5 \mathrm{Myr}$ ), where it represents a balance between incision, sediment supply and net accommodation space created. The front does not migrate further towards the inlet position of the axial delta, due to the slight dominance of regional flexural subsidence over detachment-induced uplift, which compensates the incisive effect of eustatic sea-level fall. In experiment 3 , the detachment-induced uplift component is larger, and activation of the detachment fault results in rapid formation of a single incised channel, with a high knickpoint migration rate of 10 $20 \mathrm{~km} \mathrm{kyr}^{-1}$, connecting the delta to the axial inlet. The bulk of the axially fed material bypasses the upper deltaic plain and is deposited as a small deep-water delta.

After cessation of detachment activity at $0.5 \mathrm{Myr}$, regional subsidence is no longer counteracted by detachmentinduced uplift (Fig. 7, 0.75 and 1.0 Myr). Consequently, the lower delta plain is flooded and the active delta retreats towards its inlet position, while showing bifurcating channel patterns again.

Subsequent activity on the detachment fault at $1.0 \mathrm{Myr}$ results in decreased thrust-top accommodation space and renewed progradation of the axial delta (Fig. 7a, 1.25 Myr). Again experiment 2 is characterised by multiple linear drainages on the lower delta plain, but at $1.5 \mathrm{Myr}$ a single, incised axial valley is created, implying that all sediment is bypassed to deeper water. The same change occurs earlier at $1.25 \mathrm{Myr}$ in experiment 3 (Fig. $7 \mathrm{~b}$ ), because the thrusttop basin here has a larger accumulative elevation above base level.

In both experiments, the basin-margin alluvial fans prograde due to the gradual increase of orogenic topography and supply. Progradation is interrupted by shallow marine transgressions during detachment quiescence. During detachment fault activity and basin emergence, a collector river is formed at the toes of the alluvial fans in experiment 2, which is susceptible to incision during syntectonic eustatic sea-level fall (Fig. 7a, 0.5 and 1.25 Myr).

\section{Evolution of accommodation}

The competition between regional flexural subsidence and local thrust-induced uplift controls the evolution of accommodation space in the thrust-sheet top basin (Fig. 6).
The resulting trend is modulated by the sinuous sea-level fluctuation. During activity of the frontal thrust, the accommodation space on the thrust-top platform is stepwise reduced with increasing detachment angle in experiments $1-3$, and is periodically removed all together in experiment 4. During detachment quiescence, the flexural subsidence induced by thrust loading of the orogenic wedge predominates, increasing the accommodation space generated on the thrust-top basin (Fig. 6).

During detachment activity, a larger detachment angle results in increased incision susceptibility of the delta front by eustatic sea-level falls, as these falls are less compensated by regional flexural subsidence. The maximum rate of relative sea-level fall increases from 0.25 (experiment 1) to $0.45 \mathrm{~m} \mathrm{kyr}^{-1}$ (experiment 3 ) with increasing detachment angle (Fig. 6).

Indirectly, sea-level forcing also influences the accommodation trend by isostatic adjustment upon sea levelinduced delta progradation and loading. However, this contribution is small, approximately $10 \%$ of the flexural subsidence and is therefore not visible in the curve of Fig. 6.

\section{Thrust-sheet top basin sequence architecture}

The sequence architecture of the thrust-sheet top basin fill in each experiment is shown as a fence diagram of two orthogonal lithological sections, selected from the threedimensional dataset at simulation after $1.5 \mathrm{Myr}$ of simulation time (Fig. 8). It is evident that the sediment thickness accumulated in the thrust-top platform decreases with increasing detachment angle and with flexural rigidity (experiment 1, $\sim 400 \mathrm{~m}$; experiment 2, $\sim 250 \mathrm{~m}$; experiment $3, \sim 175 \mathrm{~m}$ and experiment, $4 \sim 80 \mathrm{~m}$ ).

The stratigraphy of experiment 1 is marked by multiple stacks of prograding, coarsening-up clinoforms overlain by delta-top sands and thin carbonate onlaps, reflecting the eustatic sea-level fluctuations. Time lines corresponding to initiation and cessation of activity of the underlying detachment fault are highlighted in red (Fig. $8 \mathrm{a}-\mathrm{d}$ ). In experiment 1 , activity of the detachment fault is difficult to read from the stratigraphic pattern, because the eustatic signature dominates the stratigraphy. However, minor decreases in thickness of syn-tectonic eustatic-controlled cycles are recognisable together with enhanced progradation of coarsening-up clinoforms, implying reduction of the rate of accommodation generation in the thrust-sheet top basin. During the second phase of detachment activity, the clinoform break progrades within $0.5 \mathrm{Myr}$ towards a final position above the strike-slip fault to the adjacent marine basin. In experiment 2, the decreased thickness of syn-tectonic strata clearly accounts for the overall decrease in thickness (Fig. 8b). The eustatic cycles are thinner and the sea-level falls are characterised by increase of the sand content and high interconnectedness of the sandy delta-top layers at the expense of the fine-grained marine intervals. However, they are partly separated by thin marine carbonate onlaps, indicating a continuous 
(a)

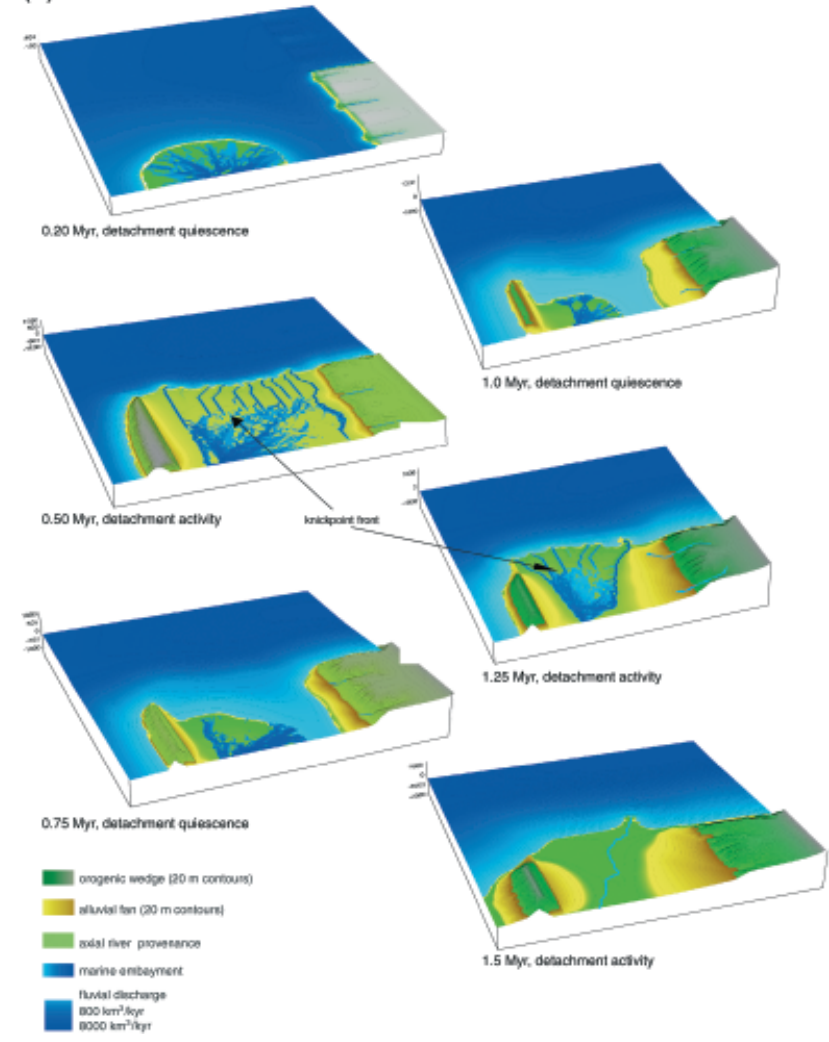

(b)

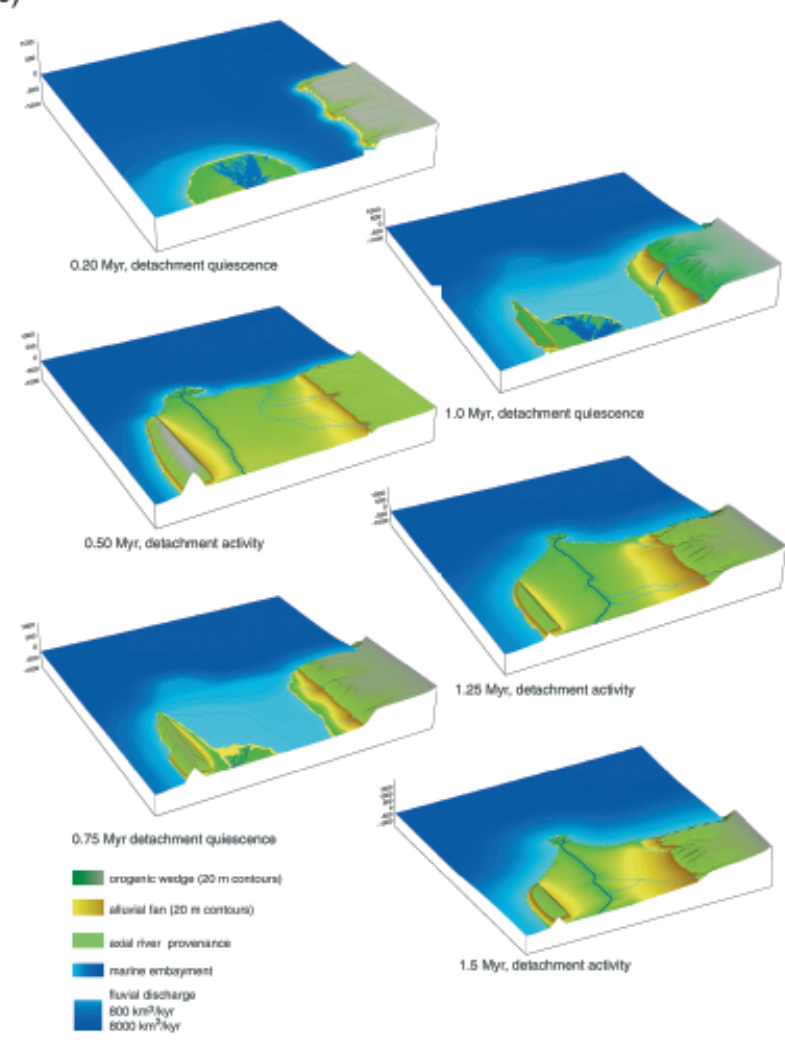

Fig. 7.(a) Successive steps in the landscape evolution of the thrust-sheet top basin, during experiment 2 , with a $4^{\circ}$ detachment angle. Initially, the basin is occupied by a single delta cone $(0.2 \mathrm{Myr})$ with a bifurcating drainage pattern. Upon activation of the detachment, the delta system progrades and becomes susceptible to eustatic-induced incision on the lower delta plain (straight single channels at 0.5 , 1.25 and $1.5 \mathrm{Myr}$ ). Detachment quiescence results in dominance of regional flexural subsidence and retreat of the delta across the thrusttop platform $\left(0.75\right.$ and $1.0 \mathrm{Myr}$ ). (b) Landscape evolution of the thrust-top basin during experiment 3 , applying a $6^{\circ}$ detachment angle. This evolution is similar to experiment 2 although syn-tectonic eustatic sea-level fall is now able to carve a single incised valley into the delta plain. Much of the sediment fed to the system during the intervals of detachment activity is bypassed to the adjacent marine basin.

marine influence of $20 \mathrm{~km}$ into the delta-plain of the thrust-sheet top basin during syn-tectonic, eustatic sealevel highs. This type of response is comparable with the observations in parts of the Montanyana Group, where sheet sandstones are well developed but interleaved by thin marine intervals (Marzo et al., 1988). The syn-tectonic time lines merge locally in the sandy intervals, due to erosion and incised-valley formation. The incision is developed at the transition from detachment quiescence to activity, marked by a Type-1 unconformity, developed during the first syn-tectonic, eustatic sea-level lows.

Incision is more evident in experiment 3 , where time lines bend down in the basin centre (Fig. 8c). This implies that the basin axis position is repeatedly used for incision, in particular during syn-tectonic intervals where time lines merge. No carbonate or fine-grained onlaps are recognisable within the syn-tectonic sequences, implying that the delta plain is not influenced by sea-level highstands, only by incision induced by the sea-level fall.

In experiment 4 (Fig. 8d), a lower regional flexural subsidence rate of $\sim 0.18 \mathrm{~m} \mathrm{kyr}^{-1}$ clearly effects the stratigraphy in the entire model space. On the thrust-top basin, the $100 \mathrm{kyr}$ stacking cycles are highly compressed and, with ex- ception of the alluvial fan deposits, the syn-tectonic strata are lacking. The marine basin now shows the complete stacking cycles. Note that at the end configuration of experiments 3 and 4 the complete thrust-sheet top basin is on average some $50 \mathrm{~m}$ above base level, due to the last phase of detachment-induced uplift.

\section{The delta-slope stratigraphy in the adjacent basin}

Figure 9 shows the three-dimensional relationship between the incised valley fill systems of the thrust-sheet top basin and the corresponding delta slope deposits in the adjacent basin at the end of experiment 3. Two incised systems, a lower and an upper one, are represented as a string of voxels. Both are formed during phases of detachment fault activity. The lower fill $(0.2-0.5 \mathrm{Myr})$ consists of two to three obliquely stacked channel belts, an amount that corresponds to the number of eustatic sea-level falls during the first syn-tectonic phase. The upper incised valley fill (1.0-1.5 Myr) also consists of multiple channel belts, but these are stacked vertically and only split in the downstream direction where they crosscut the cross-section. 
(a)

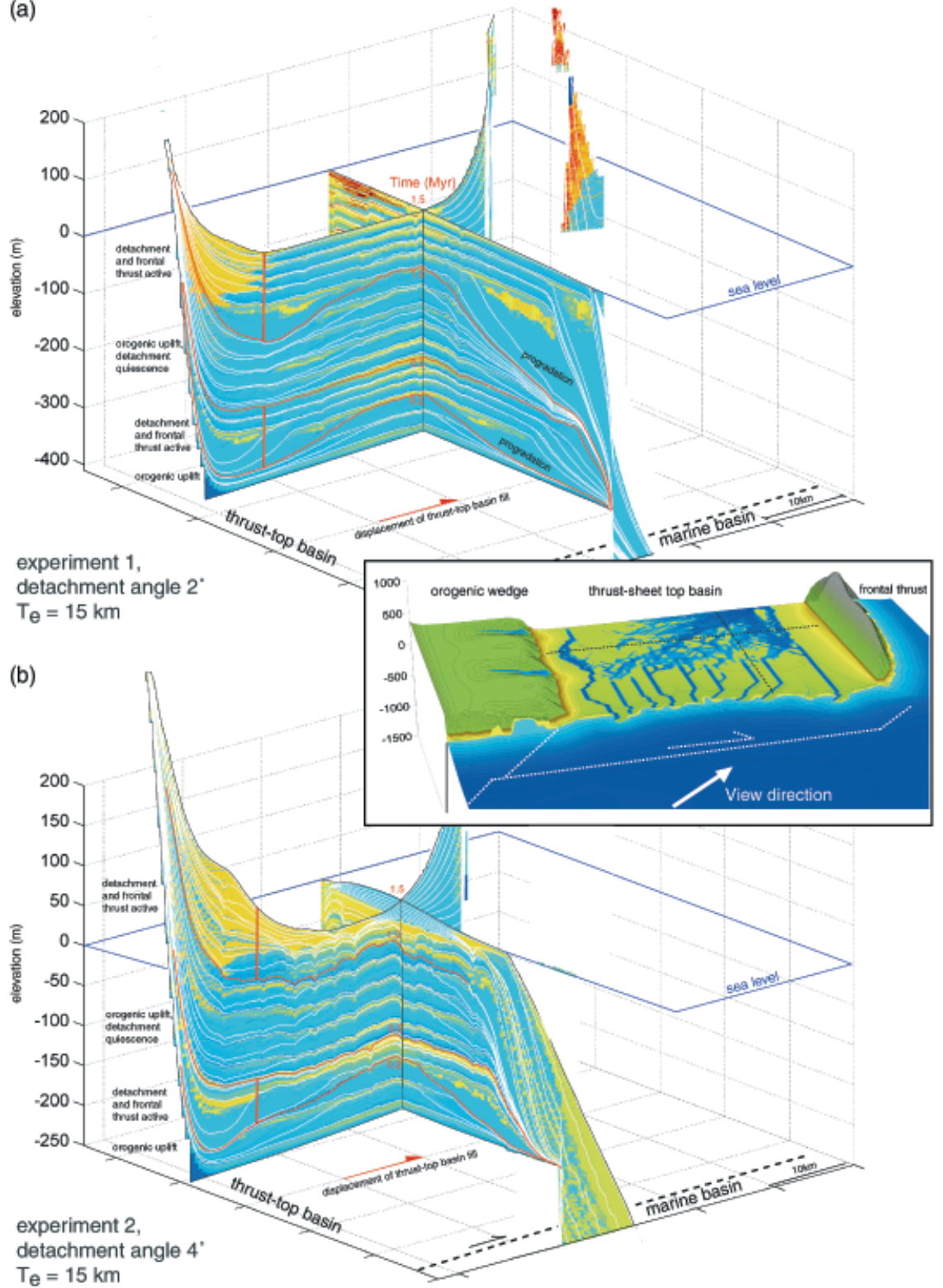

Fig. 8. Fence diagrams illustrating the stratigraphic response to a shifting balance between regional flexural subsidence and detachment-induced uplift. A stepwise increased detachment angle (experiments 1-3), or larger flexural rigidity (experiment 4) results in enhanced delta progradation, increased interconnectedness of sandy fluvio-deltaic facies at the cost of fine-grained intervals, and susceptibility to incision by the longitudinal river. White lines show time lines at $50 \mathrm{kyr}$ intervals. Inset shows the location of the crosssections (dotted black lines), and the view direction for (a)-(d). Nb: different vertical scales are used.

With respect to the lower valley fill, the upper one has been shifted toward the orogenic wedge by over a distance of $10 \mathrm{~km}$ (Figs 7b and 9). Vertical channel stacking and the shift are indicative of the axial river being locked in the thrust-sheet top basin axis during the second phase of detachment fault activity. Both valley fills are connected over the lateral ramp of the thrust-sheet top basin to a coarsening-up delta lobe, deposited in the deep-water sub-basin. In this basin, the successive phases of detachment activity and quiescence are recognisable as lobate bodies characterised by high sedimentation rate $\left(>0.5 \mathrm{~m} \mathrm{kyr}^{-1}\right.$, Fig. 9b) separated by a condensed section of closely stacked time lines (0.5-1.0 Myr, Fig. 9b).

\section{Correlation of mass-flow events to the eustatic signal}

A synthetic well (Fig. 10) through the deep marine basin fill illustrates the relation between mass-flow events and eustatic sea-level fluctuations. The well is complemented by a graph showing the eustatic sea level at the time of deposition of each individual layer. As a result the derived eustatic curve is not symmetrical, but stretched or compressed by differences in the sedimentation rate of the deposited stratigraphy. As in the fence diagram (Fig. 9), the bulk of the deep-marine sedimentation in the well is synchronous with the phases of detachment activity, sepa- 
(c)
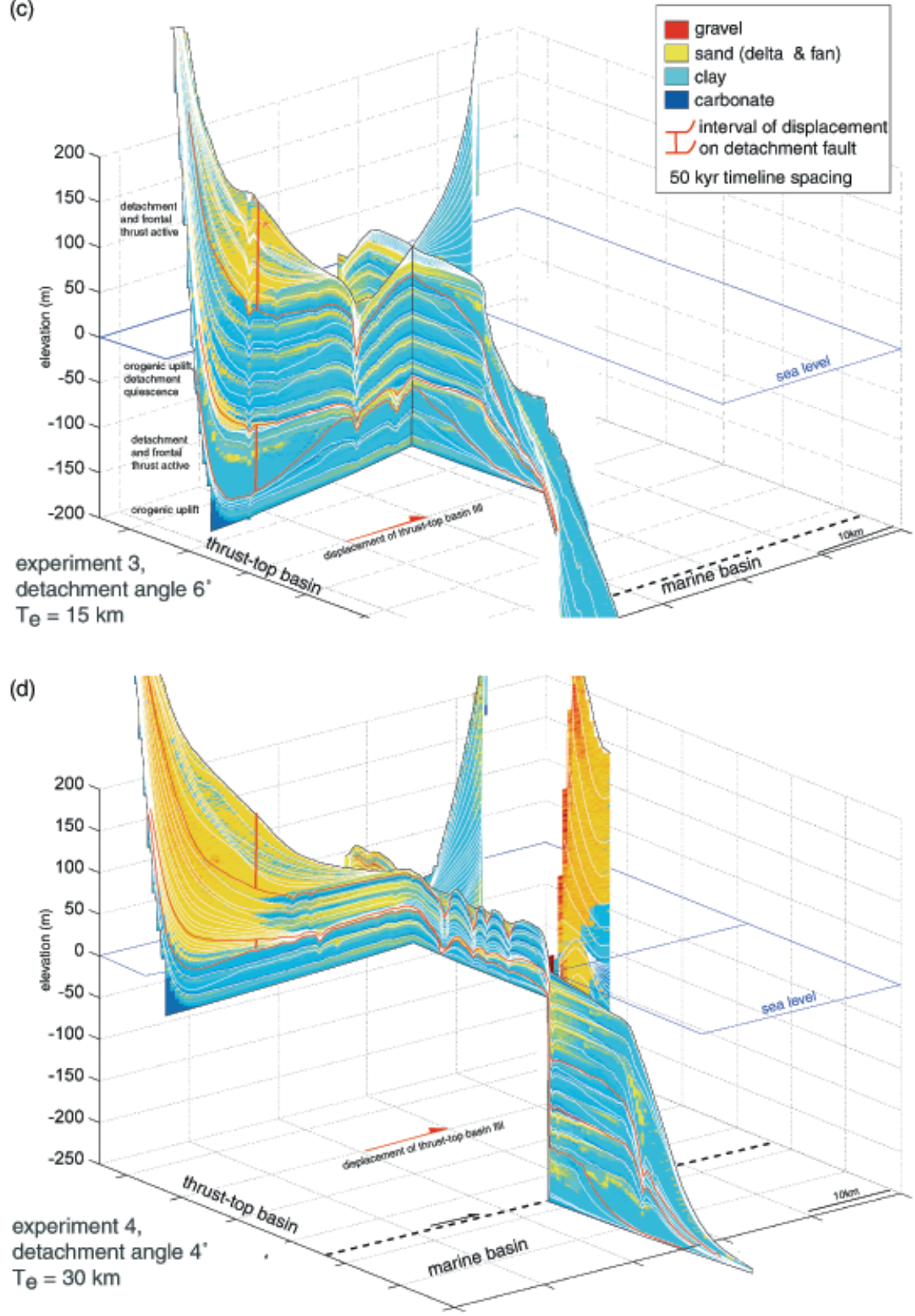

Fig. 8. Continued.

rated by a condensed section corresponding to detachment quiescence. The first interval $(-575$ to $-450 \mathrm{~m})$ represents a coarsening-up section through the lowermost deep-water delta lobe, topped by one of the axial channel lags and two carbonate-rich beds, indicating the transition from forced regression by detachment activity to transgression during detachment quiescence. In the second stratigraphic interval ( -450 to $-100 \mathrm{~m}$ ), there is a correlation between the presence of mass-flow sand beds in the well and rises of the eustatic sea level.

\section{DISCUSSION}

\section{Fluvial patterns}

It is clear from the above experiments that the fluvial drainage in thrust-sheet top basins is influenced by the angle and activity pattern of the detachment fault. During detachment quiescence the rise of relative sea level due to regional flexural subsidence results in rapid backfilling, relocating fluvial channels and the formation of a single delta cone.

During translation along the detachment, accommodation space is reduced, the fluvial system progrades and the clinoform break becomes a line source of small deltas fed through a row of small, incised valleys. Alternatively, at a steeper detachment angle and faster fall of relative sea level (Figs 6 and 7b) a single delta is formed at the clinoform break fed by a major incised valley system, which is locked between basin-margin alluvial fan profiles (Figs $7 \mathrm{~b}$ and 8).

The syn-tectonic alluvial fan and longitudinal river progradation observed in the model has an implication 
(a)

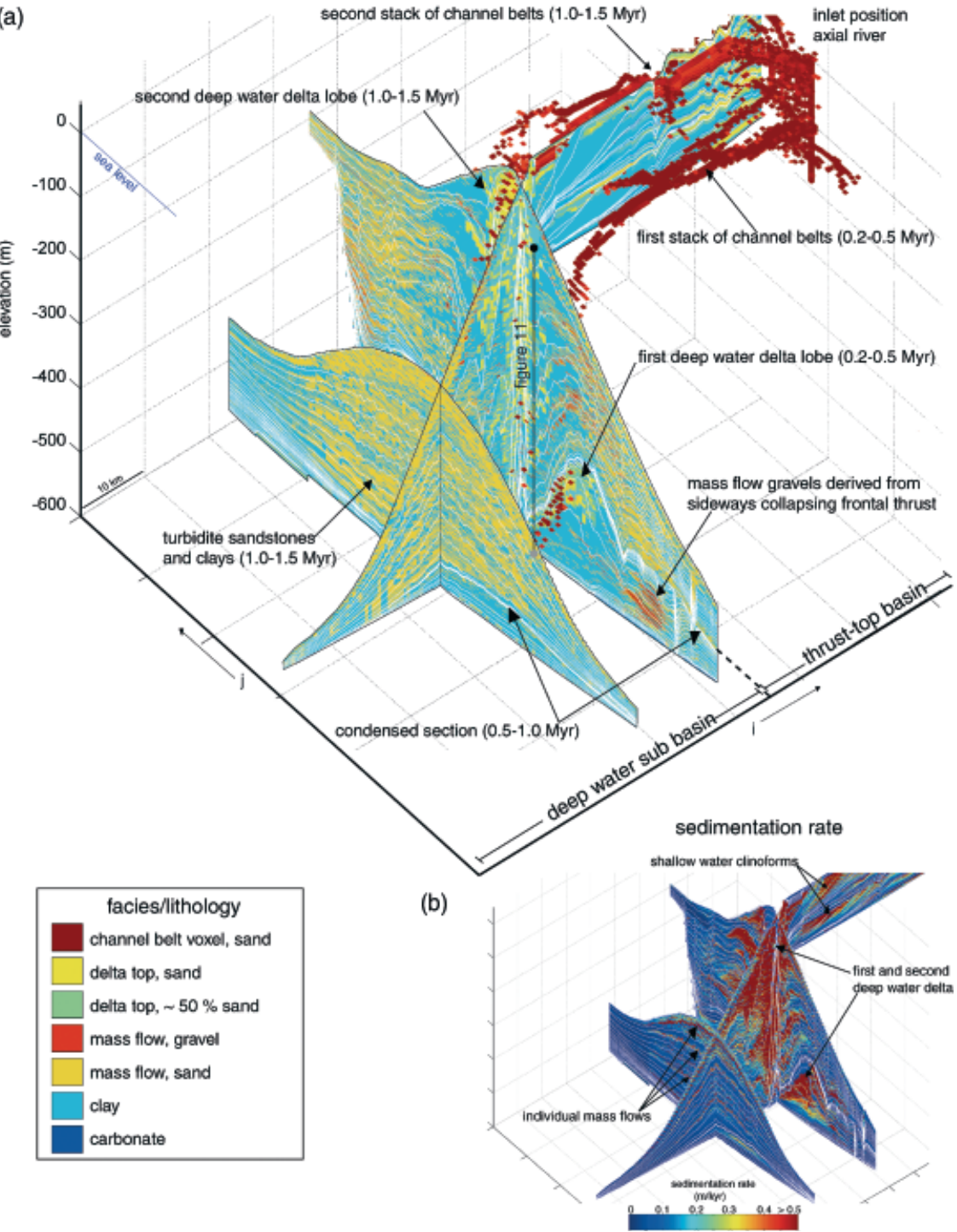

Fig. 9. Lithological fence diagram of experiment 3 showing the connection between the thrust-sheet top basin and the deep-water subbasin. Two incised valley fills, corresponding to the phases of detachment activity, pass over the lateral ramp into deep-water delta lobes. These lobes are dominated by mass-flow beds and high sedimentation rates $\left(\sim 0.5 \mathrm{~m} \mathrm{kyr}^{-1}\right)$, and are deposited during intervals of detachment activity. A condensed section represents the quiescence phase of the detachment fault $(0.5-1.0 \mathrm{Myr})$.

for the simplistic 'two-phase' concept of foreland basin fluvial patterns (Heller et al., 1988). In this concept longitudinal flow close to the thrust front is associated with syntectonic subsidence, whereas dominance of transverse flow is indicative for quiescence or isostatic rebound by erosional unloading. In a foreland basin underlain by active hinterland-dipping detachments, transversal and longitudinal progradation of alluvial systems may instead be due to a reduction of accommodation space along a considerable length of the foreland basin by translation over the detachment fault, instead of isostatic rebound.

\section{Stratigraphy}

The accommodation space in the modelled thrust-sheet top basin is sensitive to small increases in the detachment angle. The basin-scale stratigraphic stacking pattern is thus a function of the balance between regional flexural subsidence and thrust-sheet displacement-induced uplift. Displacement results in sand-sheet amalgamation, unconformities or even incised valleys, the intensity of the response depending on the steepness of the angle of the detachment fault. This sedimentary response to detachment activity phases, punctuates the overall basin subsidence and fine-grained sedimentation, just as observed in the Montanyana Group (Fig. 2).

\section{Castissent formation}

A well-studied but controversial section of the Montanyana Group is the Castissent Formation or megasequence (Figs 1 and 2). Characterised by amalgamating sheet sandstones and pronounced progradation into the lower delta plain and the Ainsa Basin, it has been interpreted as an in- 


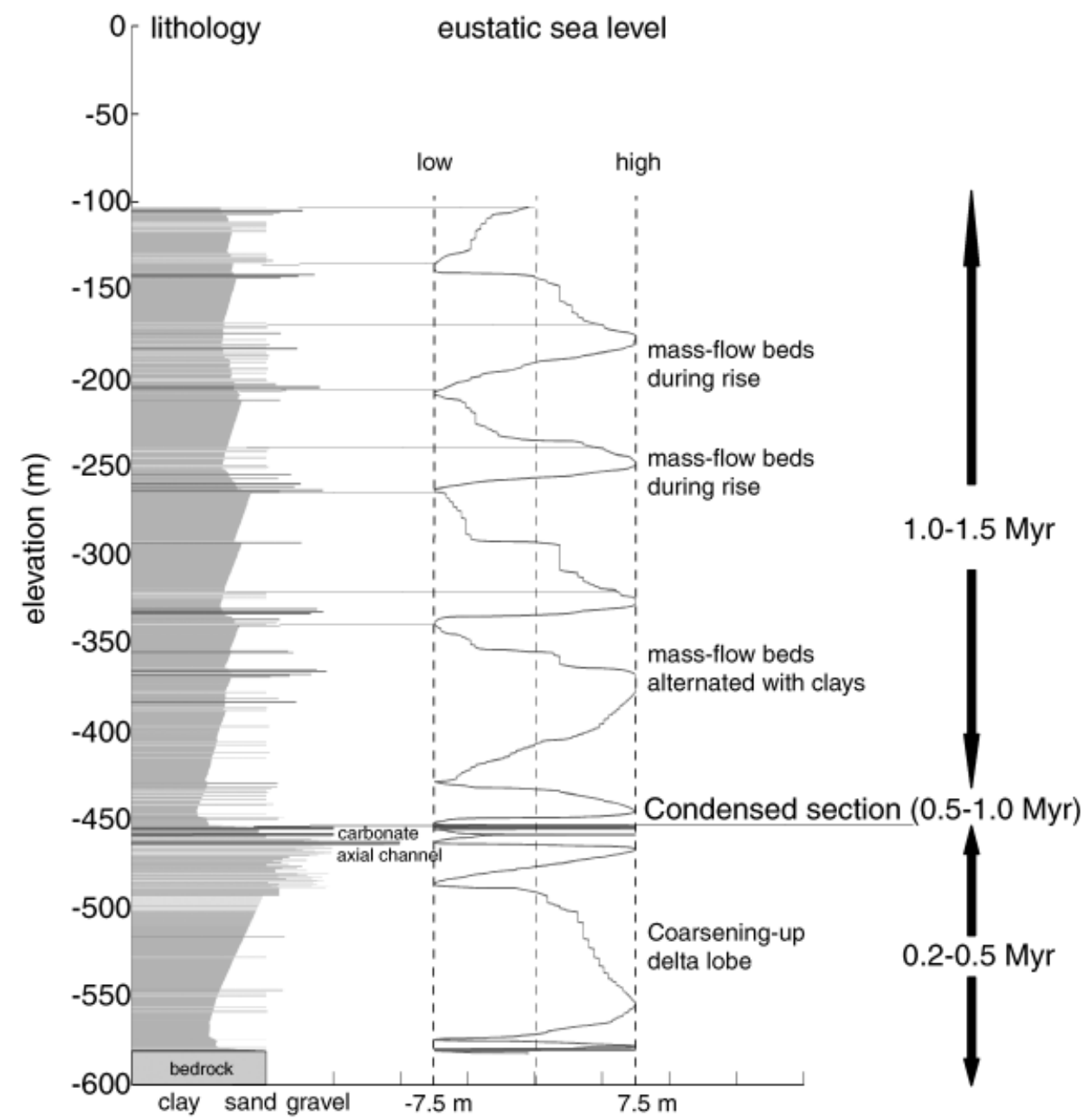

Fig. 10. Synthetic well taken from the deep marine sub-basin, showing two intervals of syn-tectonic sedimentation $(0.2-0.5$ and $1.0-$ $1.5 \mathrm{Myr})$, separated by the condensed section $(0.5-1.0 \mathrm{Myr})$. Comparison of the well to the eustatic curve indicates that the timing of mass-flow deposition corresponds to syn-tectonic eustatic rise in the well top. Note that this reconstructed curve is not symmetrical, because it is matched to the depositional age of the stratigraphy and the deposition rate is highly non-steady.

cised valley-fill sequence, related to the Ypresian sea-level fall at 51.3 Myr (Marzo et al., 1988). However, several characteristics of the Castissent Formation do not validate this interpretation. Improved dating constraints on existing correlations set the base of the formation at $51.7 \mathrm{Myr}$ instead of $51.3 \mathrm{Myr}$ (Nijman, 1998). There is no clear Type-1 unconformity at the base but instead a marine onlap that correlates with thrust-flank unconformities. The average sedimentation rate was only slightly less than that of the underlying megasequence. Moreover, the individual sheet sandstones are sandwiched between widespread brackishmarine onlaps (Marzo et al., 1988; Nijman, 1998), indicating a continuous marine influence throughout deposition. These inconsistencies within the incised valley interpretation were recognised by Nijman (1998), who interpreted the formation as the result of highstand progradation in response to a previous phase of tectonic loading and subsidence. Considering the model results, the Castissent Formation more likely represents a phase of displacement-induced reduction of accommodation space, resulting in forced regression and an increased inter- connectedness of sandstones at the cost of fine-grained intervals, but without excluding marine influence. The resemblances between the Castissent Formation and the synthetic stratigraphies are not interpreted as a validation of the numerical model, but they merely represent an argument for our tectonic explanation for the deviating characteristics of the Castissent Formation.

\section{Are other basins controlled by the same mechanism?}

The same mechanisms could apply to the Pyrenean Ripoll thrust-sheet basin, which also shows phases of accelerated axial progradation (Ramos et al., 2002). Paleomagnetic work in the late Cretaceous to Eocene Axhandle Piggyback Basin of Central Utah indicates that sedimentation rates alternated between times of rapid $\left(0.05-0.25 \mathrm{~m} \mathrm{kyr}^{-1}\right)$ and low $\left(<0.02 \mathrm{~m} \mathrm{kyr}^{-1}\right)$ accumulation, and that periods of non-deposition or even incision also occurred (Talling et al., 1995). Lawton \& Robinson (2003) identify two longitudinal fluvial systems supported by a detachment ramp and also characterised by a high net to gross aspect. These 
are the Santonian Straight Cliffs Formation in Southern Utah and the Mid-Late Campanian Price River Formation, which were both deposited during rapid advance of the thrust front. More extreme end members of the mechanism are probably found in the Plio-Pleistocene thrust-sheet depozones of the western Taiwan foreland basin, where accommodation space was not only reduced by tectonic translation, but even actively destroyed. Here, deposition was punctuated by phases of deep incised valley formation and creation of basin-wide unconformities every $200-700 \mathrm{kyr}$, which do not correspond to falls in eustatic sea level (Chen et al., 2001).

\section{Temporal sediment storage in thrust-sheet top basins}

In segmented foreland basins, the timing of accumulation on the thrust-top basin and bypass to adjacent marine basins is much debated (Mutti, 1985; Ricci-Lucchi, 1986; Pickering et al., 1995; Pickering \& Corrigidor, 2003). In the model experiments, bypass of the thrust-sheet top depozone occurs during detachment activity and is recognised by increased sedimentation in the deep-water sub-basin (Fig. 9). This behaviour of the model is consistent with the interpretation of tectonic-controlled sediment partitioning between the Tremp and Ainsa basins by Mutti (1985). He concluded, based on correlation of sequence boundaries between both basins, that the Ainsa turbidite lobes are synchronous with phases of activity along the Tremp-Ainsa lateral ramp (Fig. 2).

The deep-water sediment geometries calculated by the model are a starting point for modelling this famous field analogue for tectonic-influenced deep-water turbidite deposition. The aim was to model alluvial stratigraphy and adjustments need to be made to the model in order to incorporate more physically based submarine transport algorithms and syn-sedimentary blind thrusts, which influence the orientation of the Ainsa lobes and their stacking pattern.

The superimposed eustatic fluctuation in the model experiment leads to repetitive deposition of mass-flow beds. The timing corresponds to phases of syn-tectonic eustatic rise. This behaviour is easily explained. During a phase of eustatic sea-level fall a delta top progrades. It becomes subject to drowning and collapses during the subsequent eustatic rise and the chance of a collapse increases as the delta top and front submerge. Obviously, changing the value of the friction angle, sediment cohesion or applying another, more sophisticated triggering threshold will lead to a change in timing of the mass-flow events.

Despite the syn-tectonic spilling of sediment into the adjacent basin, the supply is insufficient to fill this continuously subsiding basin in experiments 1,2 and 3 . In experiment 4 , the regional subsidence rate is reduced from 0.32 to $0.18 \mathrm{~m} \mathrm{kyr}^{-1}$ by doubling the effective elastic thickness of the lithosphere. The resulting thrust-sheet top stratigraphy resembles that of experiment 3 , showing pronounced incisions, syn-tectonic sheet sandstones. How- ever, now a more complete delta stratigraphy is developed in the subbasin.

\section{CONCLUSIONS}

Numerical experiments show that the competition between rates of regional flexural subsidence and local detachment-induced rock uplift controls the accommodation space evolution and the stratigraphic patterns in a marine-influenced thrust-sheet top basin. During activation of the detachment fault, the fluvio-deltaic system carried by the thrust-sheet progrades and part of the sediment supply is spilled over into adjacent basins. The intensity of the progradation, the interconnectedness of fluvial sheet sandstones and the sensitivity to the formation of incised valleys increase with the angle of the detachment fault. The mechanism could explain the Castissent Formation as a phase of reduced accommodation space by translation over an underlying detachment, instead of an incised valley fill sequence formed by eustatic sea-level fall. During quiescence of the detachment fault, the flexural subsidence becomes the predominant component in the accommodation space balance above the thrust-sheet top basin. Sediment is temporarily stored on the thrust sheet as the deltaic system retreats while leaving the adjacent deep-water basin starved.

\section{ACKNOWLEDGEMENTS}

We thank Greg Tucker for his permission to use the GOLEM landscape evolution code, which served as a basis for the thrust-sheet top basin model. Comments on early versions of the manuscript by George Postma and Iwan de Lugt were very helpful. Constructive reviews by Alexander Densmore, Peter Talling and Jaume Vergés improved the manuscript.

\section{REFERENCES}

Beaumont, C., Muñoz, J.A., Hamilton, J. \& Fullsack, P. (2000) Factors controlling the Alpine evolution of the central Pyrenees inferred from a comparison of observations and geodynamical models. 7. Geophys. Res., 105, 8121-8145.

Beer, J.A., Allmendinger, R.W., Figueroa, D.E. \& Jordan, T.E. (1990) Seismic stratigraphy of a neogene piggyback basin, Argentina. Am. Ass. Petrol. Geol., 74, 1183-1202.

Bentham, P. \& Burbank, D.W. (1996) Chronology of the Eocene foreland basin evolution along the western oblique margin of the south-central Pyrenees. In: Tertiary Basins of Spain, The Stratigraphic Record of Crustal Kinematics (Ed. by C.J. Dabrio), pp. 144-152. Cambridge University Press, Cambridge.

BlaIR, T.C. (1999) Alluvial fan and catchment initiation by rock avalanching, Owens Valley, California. Geomorphology, 28, 201-221.

Braun, J. \& Sambridge, M. (1997) Modelling landscape evolution on geological timescales: a new method based on irregular spatial discretization. Basin Res., 9, 27-52. 
Burgess, P.M. \& Hovius, N. (1998) Rates of delta progradation during highstands: consequences for the timing of deposition in deep-marine systems. 7. Geol. Soc. Lond., 155, 217-222.

Burkhard, M. \& Sommaruga, A. (1998) Evolution of the western Swiss Molasse Basin: structural relations with the Alps and the Jura Belt. In: Cenozoic Foreland Basins of Western Europe (Ed. by A. Mascle, C. Puigdefäbregas, H.P. Luterbacher \& M. Farnandez), Geol. Soc. Spec. Publ., 134, 279-298.

Chaleron, E. \& Mugnier, J.-L. (1993) Sequence de propagation des failles dans un prisme daccretion: une modelisation numerique. Bull. Soc. Geol. Fr., 164(1), 113-121.

Champell, B., van der Beek, P., Mugnier, J.-L. \& Leturmy, P. (2002) Growth and lateral propagation of fault-related folds in the Siwaliks of western Nepal: rates, mechanisms, and geomorphic signature. 7. Geophys. Res., 107(B6), 2111, 10.1029/ 2001JB000578

Chen, W.S., Ridgway, K.D., Horng, C.S., Chen, Y.G., Shea, K.S. \& YeH, M.G. (2001) Stratigraphic architecture, magnetostratigraphy and incised-valley systems of the PliocenePleistocene collisional marine foreland basin of Taiwan. Geol. Soc. Am. Bull., 113, 1249-1271.

Clevis, Q. (2003) Three-dimensional modelling of thrust-controlled foreland basin stratigraphy. Geol. Ultraiectina, 226, 135pp; PhD Thesis, Geosciences, Utrecht University, ISBN 90-5744-085-7, available online via http://www.library.uu.nl/ digiarchief/dip/diss/2003-0708-104559/inhoud.htm.

Clevis, Q., de Boer, P. \& Nijman, W. Differentiating the effect of tectonic pulsation and eustatic sea-level fluctuation in foreland basins filled by alluvial fans and axial deltaic systems. Sedimentology, in press.

Clevis, Q., de Boer P, . \& Wachter, M. (2003) Numerical modeling of drainage basin evolution and three-dimensional alluvial fan stratigraphy. Sediment. Geol., 163, 85-110.

Contreras, J. \& Suter, M. (1990) Kinematic modeling of cross-sectional deformation sequences by computer simulation. 7. Geophys. Res., 95, 21913-21929.

Crave, A. \& Davy, P. (2001) A stochastic 'precipitation' model for simulating erosion/sedimentation dynamics. Comp. Geosci., 27, 815-827.

De Boer, P.L, Pragt, J.S.J. \& Oost, A.P. (1991) Vertically persistent sedimentary facies boundaries along growth anticlines and climate-controlled sedimentation in the thrust-sheet-top South Pyreneean Tremp-Graus Foreland Basin. Basin Res., 3, 63-78.

Demicco, R.V. (1998) Cycopath 2D - a two-dimensional, forward model of cyclic sedimentation on carbonate platforms. Comp. Geosci., 24, 405-423.

Densmore, A.L., Ellis, M.A. \& Anderson, R.S. (1998) Landsliding and the evolution of normal fault bounded mountains. 7. Geophys. Res., 103, 15203-15219.

Dreyer, T., Corregidor, J., Arbues, P. \& Puigdefàbregas, C. (1999) Architecture of the tectonically-influenced Sobrarbe deltaic complex in the Ainsa Basin, northern Spain. Sediment. Geol., 127, 127-169.

Forman, S.L. (1990) Post-glacial relative sea level history of northwestern Spitsbergen. Geol. Soc. Am. Bull., 102, 1580-1590.

Friend, P.F., Marzo, M., Nijman, W. \& Puigdefàbregas, C. (1981) Fluvial sedimentology in the Tertiary South Pyrenean and Ebro basins. In: Field Guide to the Modern Ancient Fluvial systems in Britain and Spain (Ed. by T. Elliot), pp. 4.1-4.50. Keele University, UK.
Hardy, S. \& Poblet, J. (1995) The velocity description of deformation. Paper 2: sediment geometries and fault-bend folding. Mar. Petrol. Geol., 12, 165-176.

Heller, P.L., Angevine, C.L. \& Wilson, N.S. (1988) Two phase stratigraphic model of foreland basin sequences. Geology, 16, 501-504.

Hodgetts, D., Egan, S.S. \& Williams, G.D. (1998) Flexural modelling of continental lithosphere deformation: a comparison of 2D and 3D techniques. Tectonophysics, 294, 1-20.

Hogan, P.J. \& Burbank, D.W. (1996) Evolution of the Jaca Piggyback Basin and emergence of the external Sierra, Southern Pyrenees. In: Tertiary Basins of Spain, The Stratigraphic Record of Crustal Kinematics (Ed. by C.J. Dabrio), pp. 153-160. Cambridge University Press, Cambridge.

Holl, J.E. \& Anastasio, D.J. (1995) Kinematics around largescale oblique ramp, southern Pyrenees, Spain. Tectonics, 14, $1368-1379$.

Howard, A.D. (1994) A detachment limited model of drainage basin evolution. Water Resour. Res., 30, 739-752.

Huyghe, P., Mugnier, J.-L., Griboulard, R., Deniaud, Y., Gonthier, E. \& Faugeres, J.-C. (1999) Review of the tectonic control and sedimentary pattern in late Neogene Piggyback Basins on the Barbados Ridge Complex. In: Sedimentary Basins of the World (Ed. by P. Mann), 4, 367-386.

Karner, G.D. (1982) Spectral representation of isostatic models. BMR7. Austr. Geol. Geoph., 7, 55-62.

Kenyon, P.M. \& Turcotte, D.L. (1985) Morphology of delta prograding by bulk sediment transport. Geol. Soc. Am. Bull., 84, 1457-1465.

LaWton, T.F. \& Robinson, R.A.J. (2003) Implications of nonmarine sequence architecture for foreland basin dynamics, Central and southern Utah. Am. Ass. Petrol. Geol. Annual Meeting, Salt Lake City, UT.

LEOPOLD, L.B. \& MADDOCK, T.J. (1953) The hydraulic geometry of stream channels and some physiographic implications. $U . S$. Geol. Surv. Prof. Pap., 252, 57pp.

López-Blanco, M., Marzo, M. \& Muñoz, J.A. (2003) Lowamplitude, synsedimentary folding of a deltaic complex: Roda Sandstone (Lower Eocene), South-Pyrenean Foreland Basin. Basin Res., 15, 73-95.

Loseth, T.M. (1999) Submarine Mass Flow Sedimentation: Computer Modelling and Basin Fill Stratigraphy. Lecture Notes in Earth Sciences, Vol. 82. Springer Verlag, Berlin, 156pp.

Marr, J.G., Swenson, J.B., Paola, C. \& Voller, V.R. (2000) A two-diffusion model of fluvial stratigraphy in closed depositional basins. Basin Res., 12, 381-398.

Marzo, M., Nijman, W. \& Puigdefàbregas, C. (1988) Architecture of the Castissent fluvial sheet sandstones, Eocene South Pyrenees, Spain. Sedimentology, 35, 719-738.

Millán, H., Den Bezemer, T., Vergés, J., Marzo, M., Muñoz, J.A., Rocca, E., Cires, J., Zoetemeijer, R., Cloetingh, S. \& Puigdefàbregas, C. (1995) Palaeo-elevation and effective elastic thickness evolution at mountain ranges: inferences from flexural modelling in the Eastern Pyrenees and Ebro Basin. Mar. Petrol. Geol., 12, 917-928.

Milliman, J.D. \& Syvitski, J.P.M. (1992) Geomorphic/tectonic control of sediment discharge to the oceans: the importance of small mountainous rivers. F. Geol., 100, 525-544.

Meigs, A.J. (1996) Sequential development of a selected Pyrenean thrust fault. F. Struct. Geol., 19, 481-502.

Meigs, A.J., Vergés, J. \& Burbank, D.W. (1996) Ten-millionyear history of a thrust sheet. Geol. Soc. Am. Bull., 108, $1608-1625$ 
MejJER, X.D. (2002) Modelling the drainage evolution of a river shelf system forced by Quarternary glacio-eustasy. Basin Res., 14, 361-379.

MuÑoz, J. (1992) Evolution of a continental collisional belt: ECORS-Pyrenees crustal balanced section. In: Thrust Tectonics (Ed. by K.R. McKlay), pp. 235-246. Chapman \& Hall, London.

Murray, A.B. \& PaOla, C. (1997) Properties of a cellular braided-stream model. Earth Surf. Process. Landforms, 22, $1001-1025$.

Mutri, E. (1985) Hecho turbidite system, Spain. In: Submarine Fans and Related Turbidite Systems (Ed. by A.H. Bouma, W.R. Normark \& N.E. Barnes), pp. 205-208. Springer-Verlag, New York.

Nijman, W. (1998) Cyclicity and basin axis shift in a piggyback basin: towards modelling of the Eocene Tremp-Ager Basin, South Pyrenees, Spain. In: Cenozoic Foreland Basins of Western Europe (Ed. by M. Fernandez), Geol. Soc. Spec. Publ., 134, $135-162$.

Nijman, W. \& van Oosterhout, C.W.M. (1993) Quantitative model study of a nappe-top basin, the Eocene Tremp-Ager Basin, South Pyrenees, Spain. Stratigraphic Database and explanatory guide, Shell Exploration and Production, Rijswijk, The Netherlands.

ORI, G.G. \& FrIEND, P. (1984) Sedimentary basins formed and carried piggyback on active thrust sheets. Geology, 12, 475-478.

Oualine, S. (1997) Practical C Programming, 3rd edn. O'Reilly, Cambridge, 428 pp.

Paola, C., Heller, P.L. \& Angevine, C.L. (1992) The largescale dynamics of grain size variations in alluvial basins I: theory. Basin Res., 4, 73-90.

Peltier, W.R. (1990) Glacial Isostatic Adjustment and Relative Sealevel Change. National Academy Press, Washington, DC, pp. 7387.

Pickering, K.T. \& Corrigidor, J. (2003) Sediment sequences produced by tectonic cycles in deep marine sediments (seismo-sequences), Mid-Eocene Ainsa Basin, Spanish Pyrenees' In: Deep-Water Processes in Modern and Ancient Environments, Conference Abstract, pp. 37. CSIC-Instituto de Ciencias del Mar, Barcelona.

Pickering, K.T., Hiscott, R.N., Kenyon, N.H., Ricci LucChi, F. \& Sмiтh, R.D.A. (1995) Atlas of Deep Water Environments: Architectural Style in Turbidite Systems. Chapman \& Hall, London, 333pp.

Poblet, J., Muñoz, J.A., Trave, A. \& Serra-Kiel, J. (1998) Quantifying the kinematics of detachment folds using threedimensional geometry: application to the Mediano anticline (Pyrenees, Spain). Geol. Soc. Am. Bull., 110, 111-125.

Press, W.H., Teukolsky, S.A., William, T.V. \& Flannery, B.P. (1992) Numerical Recipes in Fortran 77. Cambridge University Press, Cambridge.

Puigdefàbregas, C., Muñoz, J.A. \& Vergés, J. (1992) Thrusting and foreland evolution in the southern Pyrenees. In: Thrust Tectonics (Ed. by K.R. McClay), pp. 247-255. Chapman \& Hall, London.

Ramos, E., Busquets, P. \& Vergés, J. (2002) Interplay between longitudinal fluvial and transverse alluvial fan systems and growing thrusts in a piggyback basin (SE Pyrenees). Sediment. Geol., 146, 105-131.

Ricci-Lucchi, F. (1986) The Oligocene to Recent foreland basins of the northern Apennines. In: Foreland Basins (Ed. by P.A. Allen), Spec. Publ. Int. Ass. Sedimentol., 8, 105-139.

Spangler, M.G. \& Hanon, R.L. (1982) Soil Engineering. Harper and Row Publishing, New York.

Stock, J.D. \& Montgomery, D.R. (1999) Geologic constraints on bedrock river incision using the streampower law. 7 . Geophys. Res., 104, 4983-4993.

Syvitski, J.P.M. \& Daughney, S. (1992) Delta2: delta progradation and basin filling. Comp. Geosci., 18/ 7, 839-879.

Talling, P.J.M., Lawton, T.F., Burbank, D.W. \& Hobbs, R.S. (1995) Evolution of latest Cretaceous-Eocene nonmarine deposystems in the Axhandle Piggyback basin of central Utah. Geol. Soc. Am. Bull., 107, 297-315.

Túcker, G.E. (1996) Modelling the large-scale interaction of climate, tectonics and topography. PhD Thesis, Pennsylvania State University, University Park, PA.

Tucker, G.E., Lancaster, S.T., Gasparini, N.M. \& Bras, R.L. (2002) The Channel-Hillslope Integrated Landscape Development Model (CHILD). In: Landscape Erosion and Sedimentation Modelling (Ed. by W.W. Doe), pp. 349-388. Kluwer Press, Dordrecht.

Tucker, G.E. \& Slingerland, R. (1996) Predicting sediment flux from fold and thrust belts. Basin Res., 8, 329350 .

van der Beek, P., Chambel, B. \& Mugnier, J.L. (2002) Control of detachment dip on drainage development of active faultpropagation folding. Geology, 30, 471-474.

Vergés, J. \& Burbank, D.W. (1996) Eocene-Oligocene thrusting and basin configuration in the Eastern and Central Pyrenees (Spain). In: Tertiary Basins of Spain, The Stratigraphic Record of Crustal Kinematics (Ed. by J. C.Dabrio), pp. 120-133. Cambridge University Press, Cambridge.

Vergés, J., Fernàndez, M. \& Martínez, A. (2002) The Pyrenean orogen: pre-, syn-, and post-collisional evolution. In: $R e-$ construction of the Evolution of the Alpine-Himalayan Orogeny (Ed. by G Rosenbaum \& G.S Lister), 7. Virt. Expl., 8, 57-76.

Wagreich, M. (2001) A 400-km-long piggyback basin (Upper Aptian-Lower Cenomanian) in the Eastern Alps. Terra Nova, 13, 401-406.

Watts, A.B. (2001) Isostasy and Flexure of the Lithosphere. Cambridge University Press, Cambridge, 458pp.

Wees, J.D. \& Cloetingh, S. (1994) A finite-difference technique to incorporate spatial variations in rigidity and planar faults into 3-D models for lithospheric flexure. Geophys. F. Int., 117, 179-195.

Whipple, K.X. \& Tucker, G.E. (2002) Implications of sediment-flux-dependent river incision models for landscape evolution. 7. Geophys. Res. B. Solid Earth, 107, doi: ETG 3-20, 10.1029/2000JB000044.

Manuscript accepted 03 February 2004 